\title{
A USUCAPIÃO ESPECIAL URBANA INDIVIDUAL E COLETIVA PELA INTERVERSIO POSSESSIONIS DA TENÇA PRECÁRIA EM POSSE AD USUCAPIONEM PRO MORADA, PRO LABORE E PRO MISERO
}

THE SPECIAL URBAN INDIVIDUAL AND COLLECTIVE USUCAPION BY INTERVERSIO POSSESSIONIS OF PRECARIOUS TENÇA IN POSSESSION AD USUCAPIONEM PRO MORADA, PRO LABORE E PRO MISERO

\section{Gilberto Fachetti Silvestre ${ }^{1}$}

\section{RESUMO}

Trata-se de pesquisa que aplica conceitos da civilística e problemáticas do direito possessório à usucapião especial urbana (coletiva e individual). Objetivou investigar respostas e entendimentos em torno do questionamento se há ou não a interversio possessionis da tença precária, matéria que ainda é uma problemática no âmbito do Direito Civil para fins de configuração da posse ad usucapionem. Posteriormente, aplicou as conclusões obtidas nesta investigação ao instituto da usucapião, nas suas modalidades urbanas individual e coletiva, bem como aplicou, também, ao direito de moradia no espaço urbano. Além da revisão bibliográfica nacional e estrangeira, a pesquisa também teve como amostra documental julgados do Superior Tribunal de Justiça que versavam sobre o assunto. Seguindo um método qualiquantitativo, a investigação procedeu à estatística dos julgados para verificar se há ou não jurisprudência em torno da matéria. Após uma análise histórica do precarium e do precario do Direito Romano, a pesquisa concluiu que a associação da posse precária a uma eterna detenção não encontra respaldo histórico e nem jurídico, de modo que nada justifica a manutenção da ideia de que não cabe a conversão da detenção ilícita por precariedade em posse geradora de usucapião especial urbana.

Palavras-chave: Precarium. Posse precária. Interversio possessionis. Usucapião especial urbana. Função social da posse.

\footnotetext{
${ }^{1}$ Professor do Departamento de Direito e do Programa de Pós-Graduação em Direito (Mestrado em Direito Processual) da Universidade Federal do Espírito Santo (UFES); Doutor em Direito Civil pela Pontifícia Universidade Católica de São Paulo (PUC/SP); Mestre em Direito Processual Civil pela Universidade Federal do Espírito Santo (UFES); Coordenador dos Grupos de Pesquisa "Desafios do Processo" e "Medicina Defensiva" (PPGDIR/UFES); Advogado. Afiliação:Universidade Federal do Espírito Santo (UFES) Lattes: http://lattes.cnpq.br/7148335865348409. ORCID: https://orcid.org/0000-0003-3604-7348 E-mail:gilberto. silvestre@ufes.br.
} 


\section{ABSTRACT}

It is a research that applies concepts of the civilistic and problematic of the possessory right to the special urban usucapion (collective and individual). It aimed to investigate answers and understandings around the question whether or not there is the intervention of possession of precarious tença, a matter that is still a problem in the scope of Civil Law for configuring possession ad usucapionem. Subsequently, he applied the conclusions obtained in that investigation to the usucapion institute, in its individual and collective urban modalities, as well as applied, also, to the right of housing in the urban space. In addition to the national and foreign bibliographic review, the research also had as a documentary sample judged by the Superior Court of Justice that dealt with the subject. Following a qualitative and quantitative method, the investigation proceeded with the statistics of the judges to verify whether there is jurisprudence around the matter. After a historical analysis of the precarium and the precario of Roman Law, the research concluded that the association of precarious possession with eternal detention does not find historical or legal support, so that nothing justifies maintaining the idea that the conversion of illicit detention for precariousness in possession generating special urban usucapion.

Keywords: Precarium. Precarious possession. Interversio possessionis. Special urban usucapion. Social function of possession.

\section{INTRODUÇÃO.}

Apesar de tema antigo e recorrente, a possibilidade ou não de saneamento do vício da precariedade e sua transformação de detenção viciosa em posse ad usucapionem ainda não encontrou uma resposta firme e unânime.

O questionamento inicial e principal desta pesquisa foi justamente se há ou não interversio possessionis da tença precária, tendo traçado o seguinte itinerário de investigação: primeiro, verificar como era a matéria no Direito Romano; segundo, sistematizar o regime jurídico da matéria na legislação e na literatura jurídica brasileiras; terceiro, aplicar as conclusões obtidas com a pesquisa bibliográfica à usucapião especial urbana nas modalidades individual e coletiva, como forma de garantia da moradia e do trabalho do precarista; e quarto, proceder a uma análise qualiquantitativa de julgados do Superior Tribunal de Justiça para constatar se há alguma jurisprudência em torno da matéria. 
Quanto à usucapião urbana, a pesquisa a abordou como instituto de direito urbanístico e tratou suas definições e problemáticas como pressupostos, pois o objetivo era trazer conclusões e conceitos da civilística e do direito possessório à matéria de caráter urbanístico, demonstrando como poderia ser feito.

É interessante antecipar a informação de que o Direito brasileiro deu contornos muito particulares à "precariedade", substancialmente diferentes daqueles contornos verificados no Direito Romano e alguns países de Civil Law da Europa e da América do Sul que foram analisados na pesquisa.

Essa pesquisa propôs, então, uma investigação de como a interversio possessionis da tença precária é definida e como pode ser aplicada, a partir de uma perspectiva teórica, à usucapião especial urbana e ao direito de moradia e trabalho. Mas, óbvia e preliminarmente a tudo, foi preciso indagar: existe no ordenamento jurídico brasileiro essa possibilidade?

As respostas, com base no entendimento do Superior Tribunal de Justiça e na literatura jurídica, não foram unânimes e nem sempre foram positivas. Por isso, paralelamente à investigação qualiquantitativa na instância especial, a pesquisa procurou sistematizar opiniões de autores brasileiros e estrangeiros em torno da possibilidade de usucapião a partir de uma tença precária originária.

O objetivo geral dessa pesquisa foi identificar se presentemente é possível reconhecer a interversão ad usucapionem da tença precária e seu motivo. Para o implemento desse objetivo, procedeu-se a estatísticas de julgados do Superior Tribunal de Justiça para verificar se há jurisprudência em torno do tema. Por óbvio, a pesquisa aprofundou, como premissa, as noções de vícios e interversio possessionis identificadas na literatura jurídica.

Para tanto, um recorte no objeto foi necessário: dos documentos de natureza judicial, utilizou-se somente os do Superior Tribunal de Justiça, em razão do seu papel unificador da jurisprudência federal. Nesse sentido, a pesquisa foi desenvolvida como uma abordagem de caráter qualiquantitativo.

A pesquisa conclui que, no caso de alguém ou um núcleo urbano deter precariamente um imóvel, mas o utilizando para fins de moradia ou trabalho por anos, essa situação não pode ser de uma mera tença. Há um interesse da sociedade em considerar relevante essa situação, especialmente se se tratar de pessoas pobres. Nesse contexto, faz todo sentido em se falar de um direito à posse daqueles que permaneceram usufruindo e dando finalidade lícita ao bem. Ou seja, em outras palavras: esses detentores, nessas condições, têm um direito à interversio possessionis da 
tença precária em posse ad usucapionem para, no espaço urbano, terem regularizada sua situação dominial.

A pesquisa, com isso, pretende oferecer aos operadores do Direito o entendimento recente e hodierno do Superior Tribunal de Justiça e da literatura jurídica brasileira acerca da caracterização da interversio possessionis da chamada "posse precária" (rectius: tença precária) e, com isso, recursos práticos à comunidade jurídica para a operabilidade da matéria em sede judicial.

\section{2. "PRECARIO" COMO VÍCIO E OUTROS SENTIDOS.}

POSSESSIO NEC VI, NEC CLAM, NEC PRECARIO.

Toda posse ad usucapionem - e, consequentemente, a usucapião em si - tem sua origem em um esbulho, ou seja, na impossibilidade de livre exercício da posse pelo legítimo possuidor em razão do apoderamento da coisa pelo usucapiente (seja de má ou de boa-fé).

O esbulho, juntamente com a turbação e a ameaça ou risco, constituem as moléstias da posse, que são situações que impedem o legítimo possuidor ou proprietário de exercer os poderes inerentes ao domínio e à posse (SILVESTRE, 2019).

O esbulho e a turbação podem ter - e geralmente o tem - sua origem nos chamados vícios da posse, que dizem respeito ao modo como ela foi adquirida. No ordenamento jurídico brasileiro é reconhecida a existência de três vícios - ou defeitos - da posse: vi (violência), clam (clandestinidade) e precario (precariedade) (BEVILÁQUA, 2003) (GONÇALVES, 2008).

A violência (vi) - da qual decorrerá a "posse violenta" - ocorre quando alguém se apodera da coisa de outrem mediante atos irresistíveis de agressão ou coação física ou moral praticados contra o legítimo possuidor ou alguém de sua família, o fâmulo ou mesmo contra a coisa. Trata-se de ato contra o qual não é possível resistir (SILVESTRE, 2019).

A clandestinidade (clam) - que dá origem à "posse clandestina" - é adquirida sorrateiramente por atos imperceptíveis e ocultos até a ocorrência efetiva do esbulho ou turbação. Fala-se em posse obtida na surdina, sem violência ou destruição de coisa e proteções. Em termos práticos, a distinção entre posse violenta e clandestina não é tão relevante para fins de tutela interdital ou publiciana (usucapião), pois as consequências são as mesmas. Essa distinção faz sentido, talvez, para fins de caracterização da extensão do dano em possível tutela indenizatória por perdas e danos e dano moral, que tende a ser maior em caso de violência (SILVESTRE, 2019).

A precariedade (precario) - que constituirá a "posse precária" - trata-se de circunstância em que a posse perde seu caráter de autorizada e passa a ser uma detenção não autorizada. 0 
possuidor ou mero detentor tem a autorização do legítimo titular da coisa para exercer o uso e o usufruto até um termo ad quem ou sine die, fixado previamente por acordo ou por notificação. Contudo, aquele que está com a coisa não cumpre a prestação de devolvê-la a quem de direito, mantendo-se indevidamente e sem autorização na posse da coisa (MOREIRA ALVES, 1997). Essa posse precária tem origem, portanto, em um inadimplemento negocial (MOREIRA ALVES, 1987). É o caso, por exemplo, do locatário que não devolve o imóvel ao final do contrato, desde que não ocorra a hipótese legal de prorrogação do contrato por prazo indeterminado prevista no $\S 1$ 10 do art. 46 da Lei no. 8.245/1991:

Art. 46. Nas locações ajustadas por escrito e por prazo igual ou superior a trinta meses, a resolução do contrato ocorrerá findo o prazo estipulado, independentemente de notificação ou aviso.

$\S 10$. Findo o prazo ajustado, se o locatário continuar na posse do imóvel alugado por mais de trinta dias sem oposição do locador, presumir-se-á prorrogada a locação por prazo indeterminado, mantidas as demais cláusulas e condições do contrato.

$[\ldots]$.

Também será o caso do amigo que não devolve ao proprietário a casa de praia emprestada por um final de semana (SILVESTRE, 2019).

A opinião quase que comum é a de que a precariedade nunca cessa (nunca convalesce) e, consequentemente, é imprestável para a usucapião (MAIDAME, 2002).

Mas, o sintagma "precario" que aparece na fórmula possessio nec vi, nec clam, nec precario em nada tem a ver com o significado de "precario", "precaria" e "precarium" construído ao longo de mais de dois mil anos de história do Direito Romano (VOLTELINI, 1922) (RICCOBONO, 2012). Daí uma primeira conclusão: "precariedade", no Direito Possessório, é um conceito polissêmico e isso pode trazer consequências e dificuldades para compreender seu regime jurídico.

Por isso, é preciso ter em mente, antes de mais nada, como aduz Luciano de Camargo Penteado (2014, p. 616), que uma coisa é a posse precária, originada do vício do abuso de confiança, e outra coisa é a posse a título precário, derivada de uma situação contratual de dependência.

O problema é que esses conceitos foram se confundindo com o tempo e interferindo no modo como se compreende os efeitos ad usucapionem que têm ou não a precariedade.

Precarium ou precario (ou "posse precária") não teve no Direito Romano e nem tem nos atuais ordenamentos de Civil Law um significado uniforme, conforme apontado por Rudolf von Ihering (2007). Constata-se que "precario" é um termo jurídico polissêmico.

Friedrich Karl von Savigny (1866) aponta que inicialmente, em Roma, a precarium consistia em concessão graciosa de terras que patrícios (patricii ou paterfamilias) realizavam em favor de 
clientes: tratava-se de um acordo revogável para uso de terras, muito semelhante ao feudalismo (DE LAS CASAS, 2019) (LAMA MORE, 2011, p. 63).

Além disso, a expansão territorial romana levou à aquisição de terras pelo Estado a título de espólio de guerra. Esses territórios ou terrenos eram designados de ager publicus e eram entregues aos clientes para cultivo e habitação. Contudo, como destaca Héctor Enrique Lama More (2011, p. 64), apenas era concedida a possessio, e não a propriedade (ager privatus) e como essa cessão poderia ser revogada a qualquer momento, o título da posse era designado de precarium: "ello no los hacía propietarios, solo mantenían la possessio, por lo que dichas extensiones de territorio permanecía como ager publicus. Éste derecho de ocupación solo era ejercido por los patricios; eran considerables los territorios que eran cultivados por los esclavos o los clientes, a quienes hacían concesiones a título esencialmente revocable (precarium)" ${ }^{\prime 2}$.

Miguel Moreno Mocholi (1951, p. 26), inclusive, afirma que o precarium era a única forma de gozo por outrem naqueles tempos. E Héctor Enrique Lama More (2011, p. 65) afirma que o instituto está na base das origens dos chamados "direitos reais limitados de domínio".

No período imperial, a precarium muda de significado: trata-se de um contrato que cria a obrigação de restituir uma coisa cedida e considera o cessionário um possuidor para fins de tutela interdital via interdicta precarium (SAVIGNY, 1866). Precarista era o cessionário-possuidor da coisa.

Conforme António dos Santos Justo (2015, p. 40 e ss e 100), por esse contrato inominado o precarista se tornava detentor da coisa em decorrência do contrato de precarium. Para ele, é nesse momento que surge a chamada "doutrina das duas posses": de um lado a posse verdadeira do precario dans e que é ad usucapionem; e de outro a detenção, que era a posse do precario accipiens. Detenção, aqui, tem a ver com o fato de o precarista exercer a posse em nome do concedente. Nesse sentido, também, Paolo Ferretti (FERRETTI, 2020).

Segundo Gerson Barboza De las Casas (2019, p. 5), Pietro Bonfante (Corso di Diritto Romano, vol. III) apresenta uma plausível justificativa para que se outorgue à situação do precarium a qualidade de posse e não de mera tenência: impedir a usucapião (usureceptio) enquanto pendente a dívida:

Otra de las explicaciones - tal vez, la más contundente- de la conservación de la figura del precario es la expuesta por BONAFANTE [sic], para quien «[...] la razón de la supervivencia del precario deriva de la función secundaria, accesoria la cual fue destinada [la garantizadora], y que es sustancialmente esta: en relación a la [enajenación en] fiducia el precario servía a impedir la usucapión

\footnotetext{
${ }^{2}$ Em tradução livre: "ele não os fazia proprietários, só mantinham a posse, pelo que ditas extensões de território permaneciam como ager publicus. Este direito de ocupação só era exercido pelos patrícios; eram considerados os territórios que eram cultivados pelos escravos e os clientes, a quem eram feitas concessões a título essencialmente revogável (precarium)".
} 
(usureceptio) de parte del fiduciante antes que fuese satisfecha la deuda [...] Pues, el fiduciante, permaneciendo normalmente en la posesión de la cosa [...] y en la justa posesión, aquella que nec vi nec clam nec precario, conforme a los antiguos requisitos de la usucapión, habría podido usucapir». Así se salvaba la contradicción de permitir el uso e impedir la usucapión; y es probable que esta fuese la única función del precario ${ }^{3}$.

Observe, então, que a "possessio precario", originalmente, não era um vício, mas uma situação jurídica especial: do cessionário para com o cedente, com o objetivo de impedir a usureceptio; e do cessionário para com terceiros, com o objetivo de possibilitar a tutela interdital possessória pelo cessionário via interdicta precarium (RICCOBONO, 1911) (SCIALOJA, 1981) (RICCOBONO, 2012).

O precarista gozava do interdictum uti possidetis contra terceiros, mas não contra o concedente; este, aliás, poderia opor a exceptio vitiosæ possessionis contra o precario dans (VOLTELINI, 1922). Havia, assim, dois tipos de posse definidos: a possessio justa, do precario dans, e a possessio injusta, do precario accipiens (JUSTO, 2015, p. 45 e 100).

Nesse sentido, António dos Santos Justo $(2015$, p. 46) se questiona por que o precario accipiens (precarista) teria posse "injusta" se a obteve porque pediu e lhe foi concedida. E encontra algumas respostas. A primeira é que

[...] o precarista possui injustamente desde o momento em que recusa restituir a coisa ao precario dans. No entanto, se, antes desta recusa, a possessio do precarista não é iniusta, só pode ser iusta e, então, persiste o problema: como é possível que o concedente e o precarista possam ter duas possessiones iustae?

Persistindo com outras respostas, António dos Santos Justo (2015, p. 46) encontra a segunda opinião:

[...] a posse é ao mesmo tempo justa e injusta: aquela goza de proteção jurídica; esta, não. Por isso, a posse do precario dans seria justa, porque protegida pelo interdictum quod precario; a do precarista seria injusta, porque não é tutelada contra o concedente. No entanto, porque é tutelada contra terceiros, em relação a estes a posse do precarista é justa e, assim, o problema mantém-se: pode haver duas posses justas (a do concedente e a do precarista)?

\footnotetext{
${ }^{3} \mathrm{Em}$ tradução livre: “Outra das explicações - talvez a mais vigorosa - da preservação da figura do precário é a dada por BONAFANTE [sic], para quem '[...] a razão da sobrevivência do precário deriva da função secundária, acessória à qual foi destinado [o garantidor] e que é substancialmente esta: em relação à [alienação em] fidúcia, o precário serviu para impedir a usucapião (usureceptio) do credor antes que a dívida fosse satisfeita [...] Bem, o credor permanecendo normalmente na posse da coisa [...] e na justa posse, aquela que nec vi nec clam nec precario, de acordo com os antigos requisitos da usucapión, poderia usucapir'. Assim, a contradição de permitir o uso e impedir a usucapião foi salva; e essa era provavelmente a única função do precário".
} 
A terceira resposta encontrada teria sido a existência de uma possessio anômala do precarista, uma vez que este não tinha a coisa com animus domini e, logo, não é um verdadeiro possuidor. Ou, então, se for uma modalidade de posse, o precarista não possui pro alieno, mas pro suo, uma modalidade sui generis de situação possessória (JUSTO, 2015, p. 46 e 47).

Conclui António dos Santos Justo (2015, p. 47) que a posse do precarista é verdadeiramente anômala: "não age como proprietário e, todavia, é um verdadeiro possuidor porque tutelado pelos expedientes que tutelam a posse, excetuando contra o concedente". E mesmo possuindo pro suo, o accipiens não poderia usucapir o domínio da coisa. A partir daí o precarista vai perdendo espaço como possuidor para passar a ser considerado detentor nos períodos históricos e nas figuras similares conseguintes.

Pode-se arriscar dizer que - ao que parece - aqui há uma associação de "precarium" com vício e detenção (vitiosæ possessionis) e com posse injusta (possessio injusta).

Assim, se essa concepção de precarium se manteve ao longo dos tempos, então a "posse precária" não poderia ser capaz de ensejar a usucapião.

Segundo Gerson Barboza De las Casas (2019, p. 6), no período pós-Justiniano o precarium se tornou um "contrato inominado", semelhante ao que hoje é o comodato. Por tal acordo, um precario dans cedia uma coisa a um precario accipiens (precarista ou accipiente); este adquiria uma posse ad interdicta - mas não uma posse ad usucapionem - e poderia usufruir da coisa com a obrigação de restituí-la quando requerida pelo precario dans. Se o possuidor precário se recusasse a restituir a coisa, o precario dans tinha a seu dispor uma tutela interdital especial, a actio præscriptis verbis. E conclui:

\begin{abstract}
lejos de haberse mantenido inmutable durante ese período la figura estudiada tuvo variaciones que determinaron sus elementos característicos. Primero debemos rescatar su carácter posesorio, pues el poseedor precario era considerado como un auténtico poseedor, sin embargo, no era un poseedor ad usuapionem. Asimismo, era una posesión conforme a derecho, pues no constituía una forma ilícita de posesión, debido a que siempre tuvo una autorización (el precarista) por parte del propietario para entrar en posesión del bien como correlato se le proporcionó una tutela posesoria directa al propietario para recuperar el mismo. De último, notamos el vínculo previo que existía entre el precario dans y el precario accipiens, un auténtico acuerdo, una forma contractual (DE LAS CASAS, 2019, p. 6) ${ }^{4}$.
\end{abstract}

\footnotetext{
${ }^{4}$ Em tradução livre: “longe de permanecer inalterado durante esse período, a figura estudada apresentava variações que determinavam seus elementos característicos. Primeiro devemos resgatar seu caráter possessório, uma vez que o possuidor precário era considerado um autêntico possuidor, no entanto, ele não era um possuidor ad usuapionem. Da mesma forma, era uma posse de acordo com a lei, uma vez que não constituía uma forma ilegal de posse, uma vez que ele sempre tinha uma autorização (o precarista) por parte do proprietário para entrar na posse da propriedade como um correlato, ele recebia uma proteção direta da propriedade para recuperá-lo. Por fim, notamos o vínculo anterior que existia entre os precários e os precario accipiens, um acordo autêntico, uma forma contratual".
} 
No período justinianeu, o precarium se firma como contrato real inominado do ut des ("dou para que me restituas") de boa-fé (bonæ fidei) (JUSTO, 2015, p. 82).

Nesse período, segundo António dos Santos Justo (2015, p. 82), a transformação do instituto em contrato real de livre revogabilidade pelo precario dans teve como principal efeito a "transformação daquela posse anômala do precarista em mera detenção cuja causa é o próprio contrato". Outrossim, houve um fortalecimento do cedente como o verdadeiro possuidor, seguindo o princípio do período clássico de que duas pessoas não podem possuir a mesma coisa ao mesmo tempo (Digesto 41,2,3,5). Desse modo, o precario accipiens é mero detentor da coisa entregue em precário: possui (possessio corpore) em nome do verdadeiro possuidor (vera possessio, com animus domini), quem seja, o precario dans.

Sobre a vera possessio do precario dans e a possessio corpore do precario accipiens, António dos Santos Justo $(2015$, p. 84) assim explica as diferenças: "Aquela tem por titular o precario dans e conduz à usucapião; esta tem por sujeito o precarista, não leva à usucapião, porque é mera detenção e é qualificada de iusta possessio porque tem a sua iusta causa no contrato precarium. A primeira é tutela por interdicta contra terceiros e contra o precarista; a segunda é tutelada apenas contra terceiros".

Também nesse período, o precario dans passou a dispor de mais um instrumento de tutela da sua posse: a exceptio vitiosæ (ou precariæ possessionis), que era uma defesa por ele apresentada quando o precarista intentava contra o interdictum uti possidetis contra aquele verdadeiro possuidor (JUSTO, 2015, p. 89).

Héctor Enrique Lama More (2011, p. 67-68) diz que existia precarium quando alguém, a título gratuito, cedia a posse de uma coisa para outrem usufruir, sendo que este teria como contraprestação a restituição da coisa na primeira reivindicação do cedente. Com o passar do tempo, essa figura contratual (inominada) foi absorvida pelo comodato.

Contra o precarista inadimplente na devolução da coisa, o precario dans guardava o interdictum quod precario, definido pelo Digesto $(43,26,2,1)$ como restituitório: "Hoc interdictum restitutorium est" (JUSTO, 2015, p. 70).

A situação possessória anômala do precarium fazia com que o precarista fosse possuidor $a d$ interdicta. Por causa disso, segundo António dos Santos Justo (2015, p. 73), o precario accipiens dispunha do interdictum uti possidetis (ou interditos restituitórios), para recuperar a coisa, e do interdictum utrubi (interditos proibitórios), para impedir a perturbação. 
Contudo, o Digesto $(43,26,17)$ proibia que o precario accipiens intentasse o interdictum uti possidetis contra o precario dans: "Qui precario fundum possidet, is interdicto uti possidetis adversus omnes, præter eum, quem rogavit, uti potest".

Aponta António dos Santos Justo (2015, p. 96 a 98 e 101) que na Idade Média tem início um declínio do precarium e dos seus interditos e surgem outras duas figuras: a precaria e o stipendium. Assim são caracterizadas por ele:

- $\quad$ Precaria: contrato pelo qual uma igreja, ordem religiosa ou pessoa singular permitia a um particular a exploração de uma coisa por determinado tempo, e essa cessão poderia ser gratuita ou onerosa, mas em regra era onerosa (diferentemente do precarium); tinha por característica a irrevogabilidade do contrato durante a vigência estabelecida, ao contrário do precário; e

- $\quad$ Stipendium: concessão que os bispos faziam aos seus clérigos e a leigos; inicialmente apresentava revogabilidade ad nutum, mas com o tempo se passou a exigir condições para a revogação.

Destaca Néstor A. Pizarro (1943, p. 845), que no regime jurídico medieval canônico da posse, vi, clam e precario eram noções alargadas para caracterizar a injusta possessio e a posse do pro possessore possidens, o injusto possuidor. Com efeito, a actio spolii e a interdicta precario também tinham seu escopo ampliado, demonstrando significação variada. Para Rudolf von Ihering $(2007$, p. 130 e ss.), a mesma ideia se estendeu ao Direito Civil comum.

O Direito francês pós-Code Napoleón concebe o precarium não como posse, mas como detenção.

Segundo Marcel Planiol e Georges Ripert (1955), a ausência de animus domini do cessionário fazia este ter a coisa a título precário. Por consequência, carecia de legitimidade aos interditos possessórios e à usucapião. Desse modo, precário era aquele que tinha a coisa, dela usufruía, mas não a tinha com animus domini. Nesse mesmo sentido, Ambroise Victor Charles Colin e Henri Capitant (1914) afirmam que o significado contemporâneo é diferente dos significados antigos: possuir a título precário é deter.

Louis Josserand (1938) entende do mesmo modo. Para ele, possuir por conta alheia torna o cessionário um mero detentor, e não um possuidor, e isso até mesmo nos casos de uso legítimo e autorizado (quando poderia haver o desdobramento da posse). Para ele, nesses casos, o precarista possui o título de outrem e, com isso, reconhece a posse e a propriedade de outrem.

No Direito espanhol e dos países sul-americanos de língua espanhola, precario ganhou, segundo Héctor Enrique Lama More (2011, p. 72-73), três contornos ou significados por ele 
designados de "situaciones posesorias dentro del precario": 1) posesión concedida; 2) posesión tolerada; e 3) posesión sin título.

Os dois primeiros tipos de posse precária são voluntários e derivam de acordos negociais similares ao comodato; já a posse precária sem título é a daqueles que carecem de qualquer título para possuir ou possuem em virtude de um título nulo. É contra essa terceira situação de precariedade que foram concebidas as ações de desahucio por precario ou desalojo por precario (LAMA MORE, 2011, p. 72) (AVENDAÑO VALDEZ et alii, 2013).

Para António dos Santos Justo (2015, p. 98) a figura do precário (precarium) desapareceu na Idade Média e as legislações contemporâneas absorveram o instituto na figura do comodato. Neste caso, o precário pode ser visto principalmente na hipótese de comodato por tempo indeterminado.

Mas no caso do Brasil a situação é diversa: é possível afirmar que o regime jurídico do comodato no Código Civil não absorveu o precarium, pois a revogabilidade daquele contrato não é de todo ad nutum. Se concluído por tempo indeterminado, sua duração é presumida e o comodante deve provar que o comodatário já utilizou a coisa pelo tempo suficiente à finalidade a que se destinou o contrato; e se por tempo determinado, a revogação está condicionada à necessidade imprevista e urgente do comodante. Vide, in verbis:

Art. 581. Se o comodato não tiver prazo convencional, presumir-se-lhe-á o necessário para o uso concedido; não podendo o comodante, salvo necessidade imprevista e urgente, reconhecida pelo juiz, suspender o uso e gozo da coisa emprestada, antes de findo o prazo convencional, ou o que se determine pelo uso outorgado.

Observe, agora, que as duas primeiras situações de posse precária aventadas por Héctor Enrique Lama More (2011, p. 72-73) se aproximam do precarium romano de concessão do ager publicus e com o contrato inominado de precario; já o terceiro tipo de posse precária se aproxima da ideia de posse viciada por abuso de confiança que existe no Direito Brasileiro (arts. 1.200 c/c 1.208 do Código Civil). Isso resta mais clarividente quando se analisa o Artículo 1921 do Código Civil y Comercial de la Nación da Argentina:

Artículo 1921. Posesión viciosa. La posesión de mala fe es viciosa cuando es de cosas muebles adquiridas por hurto, estafa, o abuso de confianza; y cuando es de inmuebles, adquiridos por violencia, clandestinidad, o abuso de confianza. Los vicios de la posesión son relativos respecto de aquel contra quien se 
ejercen. En todos los casos, sea por el mismo que causa el vicio o por sus agentes, sea contra el poseedor o sus representantes ${ }^{5}$.

Miguel Moreno Mocholí (1956), por sua vez, entende que precarium não é um tipo de posse que se revoga pela vontade de um comodante; tampouco que seja um tipo contratual especial. Segundo entende, a precarium é uma situação possessória especial que faz surgir entre proprietário e precarista uma "composse singularíssima" (singularísima coposesión), sem que por ela exista uma relação obrigatória ou contratual.

Clóvis Beviláqua (2003, p. 51) entende que a precariedade não é vício; o vicioso na situação é a recusa em devolver a coisa: "O vicio, naturalmente, não está na precariedade da posse. E' perfeitamente licita a concessão da posse de uma coisa, a titulo precário, isto é, para ser restituida, quando o proprietário a reclamar. - O vicio está na recusa da restituição, a que se obrigara o possuidor" [sic].

Já Astolfo de Resende (1937, p. 388), por sua vez, entende que precarium é a situação jurídica estabelecida entre dois indivíduos quando da cessão temporária da coisa:

Aquêle que concede a outrem o exercício do direito de propriedade, isto é, a posse natural, reservando-se a faculdade de revogar à sua vontade essa autorização, goza, com efeito, desta faculdade, e a relação jurídica que assim se forma, entre essas duas pessoas, chama-se precarium.

Com isso se vai percebendo que "precarium", "precario" e "precariedade" têm múltiplos significados históricos e jurídicos. Desse modo, "posse precária", então e nesse contexto, não seria, necessariamente, uma posse viciada ou ilícita (a tença precária); poderia ser uma situação possessória especial de um negócio jurídico especial (o precário).

A partir das codificações nacionais, a precarium foi ganhando contornos diferentes nos ordenamentos jurídicos. Jorge Avendaño Valdez (1986, p. 62) afirma: “El concepto de poseedor precario no tiene cabida sin embargo en los regímenes posesorios inspirados por Ihering. En efecto, el poseedor inmediato, a pesar de su temporalidad y aún cuando reconoce un propietario, es verdadero poseedor porque ejerce de hecho poderes inherentes a la propiedad. No hay entonces precariedad sino posesión legítima" ${ }^{6}$.

\footnotetext{
${ }^{5}$ Em tradução livre: “Artigo 1921. Posse viciada. A posse de má-fé é viciada quando se trata de coisas móveis adquiridas por roubo, fraude ou quebra de confiança; e quando se tratar de imóveis, quando adquiridos por violência, clandestinidade ou quebra de confiança. Os vícios de posse são relativos àquele contra quem são exercidos. Em todos os casos, seja pelo mesmo que causa o vício ou por seus agentes, seja contra o proprietário ou seus representantes".

${ }^{6} \mathrm{Em}$ tradução livre: "O conceito de possuidor precário, no entanto, não tem lugar nos regimes possessivos inspirados pelo Ihering. Com efeito, o possuidor imediato, apesar de sua temporalidade e mesmo quando
} 
Daí que essa pesquisa se propôs a investigar nos Códigos Civis de alguns países: 1) se existe a figura da precarium ou instituto semelhante; 2) o que significa precarium naquela legislação; e 3) se precariedade é um vício da posse. O resultado pôde ser assim sistematizado, sinteticamente:

Quadro 1 - Regime jurídico da precariedade em alguns Códigos Civis.

\begin{tabular}{|c|c|c|}
\hline País & Fundamento legal & Como é a precariedade \\
\hline Alemanha & $\begin{array}{l}\text { Bürgerliches } \\
\text { Gesetzbuch: } \S 858 .\end{array}$ & $\begin{array}{l}\text { Trata-se da previsão de defeitos na aquisição da posse } \\
\text { é viciada a posse obtida como resultado de } \\
\text { interferência ilegal e defeituosa. Veja que o rol de vícios } \\
\text { não é taxativo. O defeito consiste em privar o possuidor } \\
\text { da coisa contra sua vontade (interferência ilegal na } \\
\text { posse). Porém, aqui, a precario não aparece } \\
\text { expressamente como vício. Isso leva a concluir que o } \\
\text { B.G.B. não tratou dessa matéria especificamente, como } \\
\text { o fez o Código Civil no Brasil. }\end{array}$ \\
\hline Argentina & $\begin{array}{l}\text { Código Civil y Comercial } \\
\text { de la Nación de } \\
\text { 2014/2015: Artículos } \\
\text { 1921 e 1915. } \\
\text { Código Civil de la } \\
\text { República Argentina de } \\
\text { 1869: Artículos 2.364, } \\
2.473 \text { e } 2.480 \text {. }\end{array}$ & $\begin{array}{l}\text { Tal e qual no Brasil, o Codex argentino enumera os } \\
\text { vícios da posse, igualmente associando-os à má-fé } \\
\text { (como no caput do art. } 1.201 \text { do Código Civil brasileiro). } \\
\text { Apesar da terminologia "abuso de confianza", pode-se } \\
\text { entender isso como sendo precariedade, pois é a } \\
\text { definição tradicional. Inclusive, o Código Civil de } 1869 \\
\text { falava em posse "precaria, violenta o clandestina". A } \\
\text { "interversión" do Artículo } 1.915 \text { chama a atenção por } \\
\text { ter significado diverso daquele que existe no Código } \\
\text { Civil brasileiro. "En el derecho argentino la detención } \\
\text { precaria -a título de precario- no confiere jamás la } \\
\text { posesión, sino la simple tenencia, en consecuencia la } \\
\text { ley no le confiere el derecho a las acciones posesorias" } \\
\text { (LAMA MORE, 2011, p. 69). }\end{array}$ \\
\hline Brasil & $\begin{array}{l}\text { Código Civil: arts. } 1.200 \\
\text { c/c } 1.208 . \\
\text { Código Civil de } 1916: \\
\text { arts. } 489 \text { e } 497 .\end{array}$ & $\begin{array}{l}\text { Vício: a posse ou detenção que dele deriva é irregular, } \\
\text { ou seja, a posse é injusta, de acordo com a classificação } \\
\text { do Código Civil (art. 1.200). Essa é uma peculiaridade do } \\
\text { Direito brasileiro e uma tradição que remonta ao } \\
\text { Código Civil de 1916. }\end{array}$ \\
\hline Chile & $\begin{array}{l}\text { Código Civil: arts. 915, } \\
2194 \text { e } 2195 .\end{array}$ & $\begin{array}{l}\text { Precário é uma figura comodatária especial que atribui } \\
\text { posse ao precarista e uma tutela petitória especial, a } \\
\text { acción de precario (LEMAITRE, 2017). }\end{array}$ \\
\hline Espanha & $\begin{array}{l}\text { Código Civil: Artículos } \\
433,441 \text { e } 444 \text {. }\end{array}$ & A precario não aparece como vício. \\
\hline França & $\begin{array}{l}\text { Code Civil: Articles } \\
2263,2266,2267,2268 \\
\text { e } 2269 .\end{array}$ & $\begin{array}{l}\text { A precariedade é quando alguém possui a coisa por } \\
\text { outrem, porém o Direito Francês designa a situação de } \\
\text { "detenção precária". Essa qualificação se destina a } \\
\text { impedir a usucapibilidade da coisa cedida a outrem, ou } \\
\text { proibição de prescrever o domínio. }\end{array}$ \\
\hline
\end{tabular}

reconhece um proprietário, é um verdadeiro proprietário porque exerce, de fato, poderes inerentes à propriedade. Portanto, não há precariedade, mas posse legítima". 


\begin{tabular}{|c|l|l|}
\hline Itália & $\begin{array}{l}\text { Codice Civile: Artt. } \\
1141,1144,1147,1163 \\
\text { e 1164. }\end{array}$ & $\begin{array}{l}\text { A posse de boa-fé não é vinculada à ignorância da } \\
\text { existência de vícios, mas à ignorância de que possuir a } \\
\text { coisa lesa o direito de outrem. A precariedade não é } \\
\text { apontada como um vício. }\end{array}$ \\
\hline Portugal & $\begin{array}{l}\text { Código Civil: Artigos } \\
1253.0,1261 . \text {, 1263.o, } \\
1265.0 \text { e 1297.o. }\end{array}$ & $\begin{array}{l}\text { Foram possíveis as seguintes conclusões: 1) posse } \\
\text { precária é sinônimo de detenção; 2) a violência e a } \\
\text { ocultação são vícios da posse, mas precariedade não; 3) } \\
\text { não há previsão quanto à situação em caso de abuso de } \\
\text { confiança; e 4) existe a interversio possessionis, pela } \\
\text { qual a posse se torna ad usucapionem quando se tornar } \\
\text { pacífica (sem violência) e pública (deixa de ser oculta). }\end{array}$ \\
\hline
\end{tabular}

Fonte: Elaboração própria, 2020.

A escolha desses países tem a ver com a proximidade e a influência que a legislação e a literatura jurídica deles têm sobre o Brasil.

A pesquisa da experiência jurídica estrangeira revelou que o Brasil atribuiu à precariedade um significado diverso daquele verificado historicamente e majoritariamente em alguns ordenamentos jurídicos contemporâneos. Aproxima-se da figura romana para afastar a usucapião e da figura francesa para qualificar como detenção e impedir a usucapião. Enquanto perdurar o vício que sustém a posse violenta, clandestina e precária, tal situação não é, verdadeiramente, posse, mas um tipo de detenção não autorizada, a tença (PONTES DE MIRANDA, 1971).

E mais: aqui no Brasil, "precariedade" tem, ainda, um outro significado atribuído pela jurisprudência do Superior Tribunal de Justiça (STJ) - que mantém uma tradição jurisprudencial antiga em torno da matéria -, qual seja: no caso de ocupação de bens públicos por particulares, considera-se que essa situação constitui uma "mera detenção de natureza precária" (TORRES e MOURA, 2018). Observe que a precariedade não é assinalada como aquele vício do art. 1.200 do Código Civil, pois não há abuso de confiança nessa hipótese; se quer se trata de possuir a título precário, pois não há autorização posteriormente revogada. Mais parece que se trata da criação de uma quarta espécie de detenção, criada jurisprudencialmente. São exemplos que revelam esse significado os seguintes julgados: STJ, AgRg. no REsp. no. 851.906/DF, 4a Turma, Rel. Min. Antonio Carlos Ferreira, j. em 04/12/2014; STJ, AgRg. no REsp. no. 1.319.975/DF, 3ạ Turma, Rel. Min. João Otávio de Noronha, j. em 01/12/2015; STJ, REsp. no. 1.296.964/DF, 4a Turma, Rel. Min. Luis Felipe Salomão, j. em 18/10/2016; STJ, AgInt. no REsp. no. 1.448.907/DF, 4a Turma, Rel. Min. Maria Isabel Gallotti, j. em 16/03/2017; e STJ, REsp. no. 1.762.597/DF, 2a Turma, Rel. Min. Herman Benjamin, j. em 16/10/2018.

Não deve causar estranheza essa caracterização feita pela instância especial e por outros tribunais. Veja que essa "mera detenção de natureza precária" de bens públicos por particulares em 
muito se aproxima da cessão do ager publicus na Roma antiga, no entanto com a diferença de que em Roma a precariedade era uma situação possessória (ad interdicta), e aqui é tida por detenção, quanto a bens públicos.

Ao se analisar o art. 1.208 c/c caput do art. 1.198, todos do Código Civil, é possível detectar duas categorias de detenção e suas espécies no Direito Possessório do Brasil:

Quadro 2 - Tipos de detenção no Código Civil brasileiro.

\begin{tabular}{|l|l|}
\hline \multicolumn{2}{|c|}{ DETENÇÃO } \\
\hline \multicolumn{1}{|c|}{ Detenção lícita } & Detenção ilícita \\
\hline 1. Servidão da posse (caput do art. 1.198): são & \\
os fâmulos ou servos da posse; e & Tença (art. 1.208, in fine): é o apoderamento \\
2. Tolerância ou mera permissão (art. 1.208, & não autorizado e obtido mediante vícios. \\
ab initio): situação de apoderamento da coisa \\
por permissionários devidamente autorizados \\
pelo legítimo possuidor.
\end{tabular}

Fonte: Elaboração própria, 2020.

Dessa forma, tença não é posse, mas uma detenção ilícita da coisa (PONTES DE MIRANDA, 1971). Em sendo assim, a tença não induz a usucapião, uma vez que esta modalidade especial de prescrição exige a existência de uma posse, qual seja, a possessio ad usucapionem. Logo, o tempo de apoderamento da coisa transcorrido sob a ocorrência de vícios não computa para a usucapião (SILVESTRE, 2019).

Nesse contexto surge a classificação da posse em justa e injusta. 0 art. 1.200 do Código Civil classifica a posse em justa quando ela não for violenta, clandestina ou precária; logo - e a contrario sensu -, a posse obtida e mantida sob violência, clandestinidade ou precariedade será injusta.

Essa classificação, em alguns países, é preferida como posse regular e irregular ou, ainda, posse legítima e ilegítima (LAMA MORE, 2011, p. 76). E também variam os fatores dessa classificação - embora todos convirjam para a legalidade da aquisição da posse -, podendo-se assim sistematizar os significados encontrados nos ordenamentos e na literatura jurídicos dos países analisados:

1. modo de proteção da posse pelo Direito;

2. exercício da posse de acordo com as regras jurídicas;

3. origem da posse em relação jurídica constituída;

4. presença de título que justifique a posse;

5. presença de título válido que justifique a posse;

6. existência de vício ou defeito na aquisição da posse; 
7. existência de vício ou defeito na causa da posse (causa possessionis); e

8. exercício publicizado da posse.

Enfim, essa classificação, independentemente do nomen atribuído, diz respeito à legalidade na aquisição da posse, ou seja, se ela foi obtida por meios lícitos e regulares e assim é exercida. Veja, também, que todos são critérios objetivos de averiguação da legitimidade da posse, e não subjetivos, quando a classificação seria em posse de boa-fé e má-fé (art. 1.201).

Jorge Avendaño Valdez (1986) apresenta a posse precária como sinônimo de "posesión ilegítima". Na tradição espanhola, a classificação da posse em legítima e ilegítima também é designada de posse justa e injusta, respectivamente. Posse precária (ilegítima) é, na verdade, uma posse de boa-fé quanto aos vícios que invalidam o título (AVENDAÑO VALDEZ, 1986, p. 59). Observe, então, que a precariedade não deixa de ser um vício, mas não com o mesmo sentido que no Brasil. (Talvez até essa possa ser a raiz de o Superior Tribunal de Justiça considerar a posse de bem público como particular como "detenção precária", em razão da ausência de título; talvez, também, tenha sido por isso que no Recurso Especial no. 844.098/MG a 3a Turma entendeu que a precariedade decorria da ausência de título do possuidor).

No caso do Brasil, a classificação considera existência ou não de vício ou defeito na aquisição da posse (art. 1.200) e, que, pelo art. 1.208, enquanto existirem atos de violência e clandestinidade não haverá posse; e, pelo disposto no art. 1.200, quando há violência e clandestinidade a posse é injusta. Isso permite concluir que, então, a posse injusta não é, verdadeiramente, posse, mas tença. (Não considere, ainda, a questão sobre a precariedade, pois requererá uma discussão mais profunda).

Observe que na formulação normativa do art. 1.200: "É justa a posse que não for violenta, clandestina ou precária". Observe, agora, que o sintagma "que não for" deixa claro que a posse é justa se não for violenta, clandestina ou precária. A formulação normativa não diz, por exemplo, "quando não for obtida". Assim, deixando de existir violência, clandestinidade e precariedade, a posse se torna justa, conforme a parte final do art. 1.208 que tem a função de imunizar os vícios.

\section{A CONVALESCENÇA DAS TENÇAS VIOLENTA E CLANDESTINA EM POSSE E SEU DIES A QUO.}

Uma das conditiones sine quibus non da usucapião é o tempus (tempo), que consiste no exercício da posse continuamente por um prazo determinado pela lei em anos.

Necessariamente, a posse deve ser contínua, quer dizer, o usucapiente deverá exercer poderes de domínio por um prazo (lapso temporal) para que, finalmente, seja implementada a 
usucapião (RIBEIRO, 2007). Os prazos fixados em lei podem ser de quinze, dez, cinco, três ou dois anos, a depender da modalidade de usucapião, da situação fático-jurídica e da natureza móvel ou imóvel da coisa.

O dies ad quem do prazo poderá ser um termo resolutivo específico, com data determinada. Só que nada impede que, para privilegiar a função social da posse, seja considerado como termo ad quem uma determinada época, que consistiria em um momento histórico indeterminado, porém capaz de ser definido (SILVESTRE, 2019).

Ainda com relação ao requisito cronológico da posse ad usucapionem, cabe destacar algumas questões sobre o dies a quo do prazo.

Naqueles casos em que a posse é adquirida mediante vícios, exige-se a interversio possessionis para o início da contagem do prazo. Trata-se da convalescença - conversão, transmudação ou interversão - da posse injusta em posse justa. A posse injusta não é, verdadeiramente, posse, mas tença, uma modalidade de detenção; logo, não há como gerar usucapião. A posse justa, por outro lado, é ad usucapionem (MACCORMACK, 1974).

Dilvanir José da Costa (1998, p. 112) entende que é um equívoco falar em "posse" violenta, clandestina ou precária, pois "na verdade os três fenômenos produzem típica e flagrante detenção, e não posse. Isso em relação à vítima do atentado à posse. Em relação a terceiros, o ofensor goza de proteção possessória, o que mostra a complexidade da posse e as razões sociais da sua proteção".

António Menezes Cordeiro (2004, p. 105) define a inversão do título da posse como "uma operação pela qual o detentor obtém, ex novo, uma situação possessória, com referência à coisa que já detinha". Nesse sentido, semelhantemente, Karl Olivecrona (1938), Salvatore Riccobono (1911) e Vittorio Scialoja (1981).

Segundo S. F. D. [sic] (1861, p. 65), a interversio possessionis era uma regra da lei romana pela qual um homem que era o possuidor de uma coisa com um título emanado de outro possuidor, não poderia começar a se manter de forma independente do título que sua posse era subordinada, conforme a fórmula cum nemo causam sibi possessionis mutare. A ninguém era dado mudar a causa de sua posse e se opor adversamente ao direito sob o qual ele possuía coisa. Tratava-se da máxima nulla extrinsecus accedente causa.

Katia Mascia (2007, p. 19) revela que também na Itália não podem adquirir propriedade pela usucapião os detentores até quando se operar a interversio possessionis.

A interversio possessionis depende da cessação dos atos de violência e clandestinidade praticados para o apoderamento da posse, conforme prescrito na parte final do art. 1.208 do Código Civil: "Art. 1.208. Não induzem posse os atos de mera permissão ou tolerância assim como não 
autorizam a sua aquisição os atos violentos, ou clandestinos, senão depois de cessar a violência ou a clandestinidade".

Mas, paralelamente a isso, surge uma outra discussão, que gira em torno do momento em que ocorrerá a conversão após cessar a violência ou clandestinidade. Nesse ínterim, surgem quatro pontos de vista na literatura jurídica que merecem ser destacados:

Para a primeira linha teórica, tão logo cessem os atos de violência e clandestinidade, a posse injusta se transmuda em justa. A partir daí, tem-se posse ad usucapionem. Segundo João Manoel de Carvalho Santos (1997, p. 355 e ss.), a partir daquela cessação haverá "posse útil".

A segunda linha teórica entende que enquanto durarem os atos de violência e clandestinidade, não existe posse, mas mera detenção (ou tença). Após a cessação, surge a posse injusta, que na acepção dessa tese é posse ad usucapionem e o estigma de "injusta" se deve ao modo como foi adquirida, tratando-se de uma questão conceitual para distingui-la da posse justa, que é a adquirida sem vícios. Nesse sentido aduzem José Carlos Moreira Alves (1997, p. 358), Francisco Cavalcanti Pontes de Miranda (1971, p. 58), Eduardo Espínola (1956, p. 100 e ss) e Francisco Eduardo Loureiro (2011, p. 1.008).

Francisco Eduardo Loureiro (2011, p. 1.092), por exemplo, vê a posse injusta como um estigma, mas mesmo assim é posse (inclusive, ad usucapionem). Enquanto persiste a violência e a clandestinidade, há mera detenção; cessados tais atos, surge a posse, mas que dada a sua origem, deve ser tida por injusta:

enquanto perdurar a violência e a clandestinidade, nem posse existe, mas mera detenção. Quando cessam é que nasce a posse injusta. A posse injusta somente se converte em posse justa se mudar o que ela tem de ilícito, ou seja, a sua causa. Logo, somente com a inversão da causa possessionis, da razão pela qual se possui, é possível a conversão da posse injusta em justa, porque se retira a ilicitude de sua origem.

Para a terceira linha teórica, representada por Silvio Rodrigues (2003, p. 30 e ss) e seguido por Maria Helena Diniz (2004, p. 63), a posse injusta se transmuda em justa um ano e um dia após cessarem os atos de violência e clandestinidade, caso não haja oposição ao esbulho por parte do legítimo possuidor.

Maria Helena Diniz (2004, p. 63), ao analisar o art. 1.203 do Código Civil, verifica que o dispositivo expressa uma presunção juris tantum. A posse irá guardar o caráter de sua aquisição (viciada ou não, de boa-fé ou não) mesmo se transmitida a terceiros, em razão da regra nemo si ipsi causam possessionis mutare potest (ninguém pode mudar, por si só, a causa de sua posse): 
sendo juris tantum, tal presunção admite prova em contrário. De modo que, se o adquirente a título clandestino ou violento provar que sua clandestinidade ou violência cessaram há mais de ano e dia, sua posse passa a ser reconhecida (CC, art. 1.208), convalescendo-se dos vícios que a maculavam. O mesmo não ocorre com a posse precária, isto porque a precariedade não cessa nunca.

Ao analisar os requisitos da usucapião, Maria Helena Diniz (2004, p. 166) entende que a posse que induz usucapião há de ser justa:

Tal posse há de ser justa, isto é, sem os vícios da violência, clandestinidade ou precariedade, pois se a situação de fato for adquirida por meio de atos violentos ou clandestinos ela não induzirá posse enquanto não cessar a violência ou clandestinidade e, se for adquirida a título precário, tal situação não se convalescerá jamais.

Sinteticamente, tal ponto de vista parece ser o seguinte: após cessarem os atos de violência e clandestinidade, a posse injusta se convalesce em justa dentro de um ano e um dia; somente se dará usucapião se existir posse justa. Esse raciocínio leva ao seguinte questionamento: então, os prazos legais da usucapião são acrescidos de um ano e um dia? Por exemplo, o prazo da usucapião coletiva é de cinco anos; então, tal prazo passaria a ser de seis anos e um dia? Não se encontrou resposta a esses questionamentos na literatura e nem nos tribunais (SILVESTRE, 2019).

A quarta linha teórica se fundamenta na teoria da função social da posse. Fala-se que a convalescença ocorre no momento da primeira oportunidade que o legítimo possuidor teve para se opor ao esbulho, entretanto não agiu, logo após cessarem os atos de violência e clandestinidade. Entende-se, nesse caso, ter havido uma resignação quanto ao esbulho. Logo, tal análise dependeria do caso concreto. É o caso, por exemplo, de Flávio Tartuce e José Fernando Simão (2009, p. 60 e ss.), Sílvio de Salvo Venosa (2010, p. 88) e Marco Aurélio Bezerra de Melo (2003, p. 18 e ss).

Particularmente, é possível oferecer um outro ponto de vista. É que, nesse contexto, há que se considerar, ainda, a teoria da actio nata, pela qual a pretensão de agir depende do conhecimento da situação. $\mathrm{O}$ art. 1.224 do Código Civil adotou a actio nata para fins de perda da posse: "Art. 1.224. Só se considera perdida a posse para quem não presenciou o esbulho, quando, tendo notícia dele, se abstém de retornar a coisa, ou, tentando recuperá-la, é violentamente repelido".

Observe que a perda da posse, isto é, o esbulho, depende de dois requisitos cumulativos. 0 primeiro é a ciência do esbulho pelo legítimo possuidor (“... tendo notícia dele...”). (Evidentemente, para o possuidor presente ao esbulho a ciência é concomitante ao ato de violência e clandestinidade). Já o segundo requisito é a inoponibilidade ou resignação do legítimo possuidor 
ante o esbulho (“... se abstém de retornar a coisa, ou, tentando recuperá-la, é violentamente repelido"). Observe que, aqui não se exige a cessação da violência ou clandestinidade.

Contudo, o art. 1.224 deve ser interpretado sistematicamente em conjunto com a parte final do art. 1.208, também do Código Civil. Por essa formulação normativa, in fine, somente após cessarem os atos de violência e clandestinidade é que o esbulhador terá efetivamente a posse (SILVESTRE, 2019).

Ou seja, a perda da posse ocorre quando o legítimo possuidor toma ciência do esbulho e nada faz para retomar a coisa, após cessarem os atos de violência e clandestinidade (art. 1.224 c/c art. 1.208, in fine) (SILVESTRE, 2019).

Sabe-se que o esbulho é a perda da posse - isto é, a impossibilidade de exercer o domínio - de determinada coisa. Sabe-se, ainda, que a usucapião depende do esbulho. Ora, em sendo assim, o dies a quo do prazo usucapiente é o momento da perda da posse pelo legítimo possuidor na forma estabelecida pelos arts. 1.224 e 1.208. Aí sim, a partir desse momento, ocorre a interversio possessionis, transmudando a posse injusta (tença) em posse justa, ad usucapionem, com a ressalva de que a posse injusta não é posse, mas tença (SILVESTRE, 2019).

Pode parecer, à primeira vista, que o requisito da ciência do esbulho pelo legítimo possuidor seja anacrônico, afinal, imagine, por exemplo, o proprietário que cerca um terreno e se muda para outro país, onde mora por vinte anos sem retornar ao Brasil. Nesse período, o imóvel é ocupado por quinze anos. Não iria se dar a usucapião?

O requisito da ciência deve ser analisado de forma mitigada. $\mathrm{O}$ desconhecimento do esbulho não pode decorrer de desinteresse, desleixo e descuido da parte do legítimo possuidor. Essa "ciência" deve ser entendida como possibilidade de vir a ter conhecimento dentro do padrão de diligência e cuidado com as coisas que se espera do bonus pater familiæ (homem médio). A diligência que se espera de um proprietário é o cuidado para com sua coisa, o interesse pelo que ocorre nela. (Até porque, se o imóvel estiver sendo inutilizado indevidamente, poderá lesar a função social da propriedade prevista no $\S 1$ o do art. 1.228 do Código Civil).

\section{AS DIVERGÊNCIAS EM TORNO DA INTERVERSÃO DA TENÇA PRECÁRIA E O ENTENDIMENTO DO SUPERIOR TRIBUNAL DE JUSTIÇA SOBRE A INTERVERSIO POSSESSIONIS DA TENÇA PRECÁRIA EM POSSE AD USUCAPIONEM.}

Com relação à precariedade, a divergência quanto a um possível termo a quo da convalidação do vício também terá consequências na contagem do prazo da usucapião. 
Fala-se "possível" porque antes dessa divergência há uma outra que envolve a "posse precária", qual seja: se a tença precária se convalida em posse ad usucapionem. (Ou, em outras palavras, se há ou não interversio possessionis da precariedade).

A respeito da posse precária, existe discussão e entendimentos divergentes na literatura jurídica e em órgãos judiciais sobre ela ter ou não natureza ad usucapionem, isto é, se a "posse precária" tem o condão de dar causa à usucapião. Marcus Dantas $(2013$, p. 32) aponta que os autores brasileiros divergem sobre a possibilidade de sanar esse vício.

A tença precária é a que decorre de um abuso de confiança por parte de alguém (possuidor direto ou mero detentor), que não cumpre com o dever de restituir a coisa ao legítimo possuidor. Se há posse autorizada, logo não é exercida com animus sibi habendi (ou animus domini), sendo posse ad interdicta, sem efeitos usucapientes. Nesse sentido, José Augusto Lourenço dos Santos (2012, p. 5.523): "Quando alguém tem o controle material de uma coisa com a obrigação de devolvê-la ao proprietário ou possuidor legítimo e não o faz, pratica abuso de confiança, caracterizando-se a posse precária, isto é, a posse sem animus domini".

Na literatura jurídica brasileira há aqueles que, ao interpretarem o art. 1.208 do Código Civil, entendem não ser possível a interversio possessionis da "posse" injusta fundada na precariedade em posse justa, a exemplo de Silvio Rodrigues (2003, p. 29).

A interpretação mais restrita do art. 1.208 leva a concluir que somente a coisa obtida mediante violência e clandestinidade é que pode ser objeto de posse, após cessarem tais atos. $\mathrm{Na}$ formulação normativa não se menciona a precariedade.

Cessando os atos de violência e clandestinidade ocorrerá a interversão do título da posse, ou seja, a convalescença da posse injusta em justa. É a chamada interversio possessionis ou transmudação da posse (RICCOBONO, 1911) (SCIALOJA, 1981). Tal convalescença não ocorreria, todavia, na precariedade, conforme aponta aquele ponto de vista teórico.

Se se admitisse que a precariedade é causa de usucapião - logo, a posse precária seria $a d$ usucapionem -, o dies a quo seria o momento em que ocorre o inadimplemento quanto à devolução da coisa, ou seja, a partir do momento em que a posse se torna desautorizada. Mas aqui se encontra uma diferença quanto à posse injusta decorrente da violência ou clandestinidade: para que, nestes casos, a detenção se torne posse, é preciso que cesse o vício. Por outro lado, a precariedade nunca cessará, de modo que não haverá, aqui, a necessária interversio possessionis. E, em não se admitindo que a posse precária seja ad usucapionem, não haveria, in casu, posse, mas mera detenção, de modo que nunca haveria usucapião e, portanto, pouco importa a contagem de prazo (SILVESTRE, 2019). 
Marcus Eduardo de Carvalho Dantas $(2016$, p. 23) critica o entendimento - segundo ele de quase a totalidade dos especialistas no Brasil - de que o vício da precariedade não pode convalescer, o que seria, na sua opinião, contraditório com a defesa do saneamento dos demais vícios:

\begin{abstract}
Trata-se de uma interpretação no mínimo insólita, pois acaba tornando o vício da precariedade mais grave que os outros: se o esbulhador usa a violência física contra a pessoa do esbulhado, ele pode ver tal vício sanado das formas mais diversas; se a aquisição se dá pela recusa da restituição isso não seria de forma alguma possível, pela "quebra da confiança". Mas por que a "quebra da confiança" é mais grave que o uso da força física? Além de não parecer razoável, trata-se de uma interpretação que atribui uma vantagem injustificável em favor do proprietário. Independentemente do que ele tiver feito ou deixado de fazer para retomar o bem, o fato da posse ser injusta bloquearia a usucapião para sempre.
\end{abstract}

Contudo, no Brasil, há quem admite a convalescença da posse precária, o que, por consequência, garante ao precarista a usucapião.

Márcio Manoel Maidame (2002) entende, por exemplo, que o entendimento de que a precariedade nunca gera efeitos e nunca será ad usucapionem é uma "interpretação que dá à propriedade caráter absoluto, em detrimento de outros direitos fundamentais, como o de moradia. Por isso incompatível com a nova ordem jurídica".

Também José Augusto Lourenço dos Santos (2012, p. 5.527) chega a uma conclusão pela interversão da precariedade, interpretando o parágrafo único do art. 1.198 e o art. 1.203, todos do Código Civil:

O precarista, como definido alhures, enquanto se encontrar nessa situação, equipara-se ao detentor. E, nessa condição, os efeitos da posse lhe são estranhos não podendo se valer deles. Esta situação era coerente com a redação do artigo 487 do Código Civil revogado, o que justificava a afirmação de que a precariedade não admitia convalescimento. Após a entrada em vigor do Código Civil de 2002 a situação modificou-se. De fato, o artigo 1.198 trouxe uma inovação, no seu parágrafo único, ao permitir a realização de prova que elida a presunção de detenção. Não bastasse isso, o artigo 1.203, apesar de estabelecer que a posse mantém o mesmo caráter com que foi adquirida, admite a prova em contrário. Da interpretação conjunta destes artigos concluímos, sem maior esforço, que a posse precária pode perfeitamente transformar-se em posse capaz de gerar a aquisição da propriedade pela usucapião, bastando que o possuidor em nome alheio inverta o título da posse [...].

As formulações normativas do parágrafo único do art. 1.198 e o do art. 1.203 indicariam que se o precarista passasse a se comportar como um possuidor com animus domini, estaria ocorrendo a inversão do título. Sua "posse", então, deixaria de ser precária e passaria a ser ad usucapionem. Para 
isso, o possuidor deverá praticar atos exteriores inequívocos de oposição ao antigo possuidor e de exercício do animus domini.

Nesse sentido, Katia Mascia (2007, p. 33) destaca que a interversão não é ato volitivo subjetivo e interno do detentor: " $L$ 'inversione del possesso non può consistere in un semplice atto volitivo interiore del detentore, ma deve estrinsecarsi in uno o più atti dai quali possa comunque desumersi la modificata relazione di fatto con la cosa detenuta in opposizione al possessore" ${ }^{7}$.

Assim é que Maurizio De Giorgi (2011, p. 18) defende que a interversão se dá pela "manifestazione esteriore dalla quale sia consentito desumere che il detentore ha cessato di esercitarlo il potere di fatto sulla coisa nomine alieno e ha iniziato a esercitarlo esclusivamente nomine proprio" 8 . Quer dizer, o detentor para de possuir em nome de outrem e passa a usar a coisa como se sua fosse e com total independência do legítimo possuidor.

Segundo José Augusto Lourenço dos Santos (2012, p. 5.529), a posse ad usucapionem do precarista ficará caracterizada se houver um comportamento exterior e objetivo que altere a causa da posse: "o precarista tem que agir de tal forma que não mais reconheça a superioridade do direito do esbulhado de reaver a coisa, sendo esse comportamento o responsável pelo surgimento do animus domini". Do mesmo modo, Francisco Eduardo Loureiro (2011, p. 1118) entende que "a mudança de comportamento do precarista, pela inversão do título, permite a transformação da posse ad interdicta para posse ad usucapionem".

Aliás, para Cristiano Cícero (2005), a propósito, é irrelevante o animus domini para a interversio possessionis, conforme análise que realizou a partir do Direito Romano e do Direito contemporâneo.

Exemplos dessa interversão podem ser os seguintes, com base em ações do precarista (SILVESTRE, 2019): propositura de ação possessória em face de algum sujeito esbulhador ou turbador; pagamento de tributos que incidem sobre o imóvel, o que não fazia anteriormente; realiza de benfeitorias úteis e voluptuárias; sublocação; recusa em prestar contas ao concedente; e realiza alterações no imóvel para atender a necessidades próprias.

Logo, a convalescença, em se tratando de precariedade, depende da alteração pelo precarista da causa possessionis: passará de uma posse (ad interdicta) consentida pelo legítimo possuidor para uma tença decorrente de um inadimplemento para posteriormente se tornar em um esbulho (posse ad usucapionem) com animus domini.

\footnotetext{
${ }^{7}$ Em tradução livre: "A inversão da posse não pode consistir em um simples ato volitivo interno do titular, mas deve se manifestar em um ou mais atos dos quais se posse inferir a relação factual modificada com a coisa mantida em oposição ao proprietário".

${ }^{8}$ Em tradução livre: "manifestação externa a partir da qual é possível inferir que o detentor deixou de exercer seu poder de fato em nome alheio e começou a exercê-la exclusivamente em nome próprio".
} 
Ou seja, alteração da causa possessionis, com o surgimento de uma nova posse com características diferentes da primeira PONTES DE MIRANDA (1971). Haverá, assim, uma típica transformação da possessio naturalis em possessio civilis (CORMACK, 1880) (ALBERTARIO, 1933).

Perceba que as divergências quanto à (in)usucapibilidade na precariedade se resumem a responder à indagação: há interversio possessionis da tença precária? Revelam-se três linhas interpretativas para responder a esse questionamento, que podem ser assim sistematizadas:

Quadro 3 - Diferentes pontos de vista teóricos sobre a convalescença da precariedade.

\begin{tabular}{|c|c|c|}
\hline \multicolumn{3}{|c|}{ HÁ INTERVERSIO POSSESSIONIS DA TENÇA PRECÁRIA? } \\
\hline $1 \underline{a}$ linha de interpretação & 2a linha de interpretação & 3ํlinha de interpretação \\
\hline $\begin{array}{c}\text { Não trasmuda em posse ad } \\
\text { usucapionem }\end{array}$ & $\begin{array}{c}\text { Trasmuda em posse ad } \\
\text { usucapionem }\end{array}$ & $\begin{array}{c}\text { Trasmuda em posse ad } \\
\text { usucapionem }\end{array}$ \\
\hline $\begin{array}{l}\text { A formulação normativa do art. } \\
1.208 \text { restringe a transformação } \\
\text { da tença em posse após a } \\
\text { cessação apenas dos atos de } \\
\text { violência e clandestinidade, não } \\
\text { fazendo menção ao vício da } \\
\text { precariedade. Logo, ao excluí-lo, } \\
\text { a lei indica que a tença precária } \\
\text { não é passível de se tornar } \\
\text { posse. Reforçaria esse } \\
\text { entendimento a formulação } \\
\text { normativa do art. 1.200, pela } \\
\text { qual a posse justa é aquela que } \\
\text { não é violenta, clandestina ou } \\
\text { precária. Somente quando não } \\
\text { houver violência, } \\
\text { clandestinidade e precariedade } \\
\text { é que uma posse injusta se } \\
\text { tornaria justa. Ocorre que a } \\
\text { violência e a clandestinidade } \\
\text { cessam (art. 1.208), mas a } \\
\text { precariedade não. }\end{array}$ & $\begin{array}{l}\text { A formulação normativa do } \\
\text { art. } 1.208 \text { foi silente em } \\
\text { relação à precariedade porque } \\
\text { esta nunca deixa de existir, já } \\
\text { que é um inadimplemento. } \\
\text { Como não há o que deixar de } \\
\text { existir - como é nos atos de } \\
\text { violência e clandestinidade - } \\
\text { a precariedade já é posse per } \\
\text { se, ou seja, ipso jure: não há } \\
\text { ato (violência ou } \\
\text { clandestinidade) que } \\
\text { precisaria cessar para que } \\
\text { houvesse posse. A propósito, } \\
\text { em se tratando de } \\
\text { precariedade, sequer haveria } \\
\text { detenção: já haveria posse } \\
\text { desde seu início. }\end{array}$ & $\begin{array}{l}\text { Tomando por referência o } \\
\text { parágrafo único do art. } 1.198 \\
\text { c/c o art. 1.203, entende-se } \\
\text { que a detenção que } \\
\text { caracterizaria a precariedade } \\
\text { é uma presunção juris tantum. } \\
\text { Assim, se ficar elidida a } \\
\text { presunção inicial de tença na } \\
\text { precariedade, o } \\
\text { apoderamento da coisa } \\
\text { implicará em posse. E assim o } \\
\text { será porque a situação } \\
\text { mantém seu caráter inicial, ou } \\
\text { seja, tal e qual foi adquirida } \\
\text { (art. } 1.203 \text { ). Logo, se o } \\
\text { precarista se comportar como } \\
\text { possuidor, e não como } \\
\text { detentor, haverá a interversio } \\
\text { possessionis e a "posse" } \\
\text { precária se trasmuda em } \\
\text { posse ad usucapionem. }\end{array}$ \\
\hline
\end{tabular}

Fonte: Elaboração própria, 2020.

E, ainda, S. F. D. [sic] (1861) apresenta outra opinião: a interversão só é eficaz quando é sustentado por uma posse que não é nem ambígua nem clandestina. É necessário, para efetuar uma mudança no caráter da posse, que o proprietário tenha conhecimento do novo título, ou seja, do novo modo de agir do precarista. O exemplo é uma sublocação que não está autorizada pelo contrato. Para S. F. D. [sic] (1861) é importante que exista, nesse caso, uma negação do direito do proprietário pelo precarista. 
António Menezes Cordeiro (2004, p. 106) entende que para a inversão do título o detentor deve assumir "uma posição mais enérgica e atuação mais efetiva", dando publicidade à sua situação de verdadeiro possuidor, ou seja, de que possui em nome próprio.

Silvio Rodrigues (2003, p. 30), por sua vez, entende que a "posse precária" nunca convalesce, nunca cessa: "o dever do comodatário, do depositário, do locatário etc., de devolverem a coisa recebida, não se extingue jamais, de modo que o fato de a reterem, e de recalcitrarem em não entregá-la de volta, não ganha jamais foros de juridicidade, não gerando em tempo algum, posse jurídica".

Deveras, o dever do precarista e o direito do credor nunca se extinguem; mas a pretensão do credor, legítimo possuidor, sim, é passível de extinção, de modo que, com o tempo, o credor não poderá mais exercê-la.

Particularmente, aqui se entende de modo diverso das três linhas anteriores. A amostragem de documentos da literatura jurídica consultada nessa pesquisa não revelou um entendimento semelhante ao que se exporá. Desse modo, caso haja alguém com proposta hermenêutica no mesmo sentido e que não foi citado, fica a escusa sincera e de boa-fé, mas a pesquisa bibliográfica não apontou tal fonte.

Todas as hipóteses aventadas de precariedade - verificadas em exemplos da literatura jurídica, casos reais concretos e julgados na instância de apelação e especial - versam sobre o abuso de confiança em situações negociais (não só e especificamente contratuais). Rectius: as hipóteses versavam sobre inadimplemento negocial no que diz respeito à prestação de restituição da coisa. (A propósito, falar em "abuso de confiança" como elemento caracterizador da precariedade sói vazio; é preferível, parece, falar em inadimplemento de um negócio jurídico).

Antes da precariedade há um acordo entre o legítimo possuidor e alguém, ou seja, um consentimento de apreensão da coisa. Inevitavelmente haverá, então, o desdobramento da posse em direta e indireta e na fonte desse desmembramento da posse plena sempre haverá um negócio jurídico, ainda que tácito (art. 1.197 do Código Civil).

Tanto é assim que Edmundo Pereira Lins (1914, p. 171) aponta que desde o Digesto a posse precária (precarium possessionis) depende que o proprietário tenha realizado contratos com quem está com a posse de coisa sua. Aponta, ainda, que desde o Digesto estas são as modalidades de posse dependentes de contratos, dentre elas figurando a posse precária: emptio possessionis; conductio possessionis; precarium possessionis; possessionis depositum et commodatum; e stipulatio possessionis. 
A precariedade ocorre no inadimplemento da prestação do (antigo) possuidor direto de restituir a coisa ao legítimo possuidor. $O$ inadimplemento extingue o desdobramento da posse e cria uma situação de detenção ilícita (tença), geralmente designada de "posse injusta", conforme o art. 1.200 .

Para que a tença precária se torne posse justa (e, consequentemente, ad usucapionem), o art. 1.200 exige que não existam os vícios de violência, clandestinidade e precariedade.

violência e a clandestinidade deixam de existir, conforme a parte final do art. 1.208, quando cessarem os atos de vi e clam. É a interversio possessionis. Mas, e a precariedade? Para além das respostas das três linhas de interpretação, parece que a tença precária se converte em posse quando ocorrida a prescrição da pretensão que existe em torno do inadimplemento negocial (art. 189 do Código Civil).

No caso do jus possessionis (com caráter ad usucapionem), não há que se falar em prescrição extintiva, pois não há um desdobramento da posse em decorrência de um negócio jurídico (neste caso haveria um jus possidendi, que tem apenas caráter ad interdicta).

Mas a precariedade comporta uma situação diferente: o jus possidendi se converterá em tença, que somente após o fim da exigibilidade prestacional do negócio jurídico é que se tornará em jus possessionis (com caráter ad usucapionem).

Observe que tudo isso se diz perante o legítimo possuidor, pois perante terceiros o precarista tem posse e, aliás, nem precarista é (art. 1.196). E assim o é há séculos. Nesse sentido, Edmundo Pereira Lins (1914, p. 163):

porque o possuidor que adquiriu a posse violentamente, não a póde fazer valer contra o violentado, que se defenderá com a exceptio vitiosae possessienis, só o podendo contra terceiros. Estes, porém, não soffreram violência alguma, e, portanto, relativamente a elles, a posse não é violenta, como o ensina Paulo : « Justa an injusta adversus coeteros possessio sit, in hoc interdicto nihil refert .»

Outra coisa: essa tese não se refere à "prescrição" dos interditos possessórios. A prescrição, aqui, tem um único efeito: convalescer a tença precária em posse, ou seja, provocar a interversio possessionis para que surja uma posse ad usucapionem. Isso interferirá tão somente nos prazos de usucapião, mas em nada prejudica o exercício da rei vindicatio pelo legítimo possuidor.

E quanto ao prazo prescricional aplicado à hipótese?

Uma interpretação extensiva do sintagma "dívida" do inciso I do § 50 do art. 206 do Código Civil, de modo a abranger a noção de "obrigação", leva à hipótese do prazo quinquenal: "Art. 206. Prescreve: [...]. § 50 Em cinco anos: I - a pretensão de cobrança de dívidas líquidas constantes de instrumento público ou particular; [...]". 
"Dívida", na formulação normativa do inciso I, deve ser lido como "débito", e não necessariamente como "quantia em dinheiro". Logo, refere-se aos débitos em obrigações de dar, fazer e não fazer, podendo a dívida recair sobre o dare, o fare e o non fare.

Mas, esse prazo de cinco anos se aplica quando existir um instrumento público ou particular que represente o negócio jurídico. Na ausência dessa formalidade/solenidade, isto é, se o ato foi concluído na forma verbal, aí não haverá hipótese de prazo especial no art. 206, devendo-se aplicar, para tanto, o prazo geral de 10 anos do art. 205.

Por fim, sinceramente, nada impede que ocorra a interversão possessória da detenção precária, tal e qual ocorre com os casos de violência e de clandestinidade.

Dilvanir José da Costa (1998, p. 114) entende que todas as detenções viciosas podem se transformar em posses ad usucapionem, desde que o detentor atenda ao requisito do "possuir como seu", que marca sua pretensão desde o início. Entende, ainda, que mudanças em torno da concepção da posse e a agregação de valor e utilidade social a instituto fazem com que novas leituras devam ser feitas para transformar em domínio as pretensões que são ilegítimas em suas origens:

Tanto que se reconhece hoje a posse do ladrão como apta à prescrição aquisitiva, ante a omissão da vítima e o decurso do prazo legal. São as mudanças de concepções, decorrentes da socialização do direito e da autonomia da posse como valor ou utilidade social, capaz de se transformar em domínio independente de sua origem criminosa. O ato ilícito ou criminoso será cobrado na alçada própria, preservadas as técnicas de aquisição dos bens no interesse maior da sociedade como um todo (COSTA, 1998, p. 114).

Marcus Eduardo de Carvalho Dantas (2016, p. 16) entende que a convalescença não é requisito para usucapir e afasta a influência do tempo no saneamento dos vícios da posse:

As estratégias de saneamento têm como objetivo transformar uma posse inicialmente injusta em uma posse justa, no pressuposto de que tal requisito é imprescindível para que se possa usucapir. Mas tais estratégias são tão amplas e variadas que o saneamento se torna praticamente inevitável: para uma parte da doutrina, a simples manutenção da posse pelo curto período de 1 ano faz com que ela perca o vício de origem e se torne apta a viabilizar a usucapião.

Ainda segundo Marcus Eduardo de Carvalho Dantas (2016, p. 29), “o exercício da posse, seja qual for a sua qualificação, é mais forte do que o não uso".

Essa pesquisa procedeu à coleta de acórdãos de julgados no âmbito do Superior Tribunal de Justiça sobre o questionamento principal da investigação, qual seja, se há interversio possessionis da tença precária. 
O resultado da busca revelou que muitos recursos enfrentariam a matéria se não fosse aplicada naquele juízo recursal a Súmula no. 07: "A pretensão de simples reexame de prova não enseja recurso especial". Por isso, ou não se conheciam os recursos ou se lhes negava provimento.

A metodologia empregada na pesquisa foi a seguinte:

Quadro 4 - Procedimento de busca de julgados.

\begin{tabular}{|c|c|}
\hline Sítio eletrônico & https://scon.stj.jus.br/SCON/ \\
\hline Data & $29 / 06 / 2020$ \\
\hline Recorte temporal & não houve \\
\hline Termo de busca & "posse and precaria and usucapiao" \\
\hline Espécies de julgados selecionados & somente acórdãos \\
\hline Total de acórdãos encontrados & 23 \\
\hline $\begin{array}{l}\text { Número de acórdãos que versavam } \\
\text { sobre o objeto da pesquisa }\end{array}$ & $\begin{array}{l}17 \text { (Obs.: por causa dos termos utilizados, alguns } \\
\text { acórdãos apareciam no resultado da busca porque } \\
\text { continham as palavras buscadas, porém não diziam } \\
\text { respeito ao objeto da pesquisa e foram } \\
\text { desconsiderados). }\end{array}$ \\
\hline Método de análise & qualiquantitativo \\
\hline $\begin{array}{l}\text { Julgados que entenderam ser possível } \\
\text { a interversio possessionis da posse } \\
\text { precária }\end{array}$ & $\begin{array}{l}\text { - STJ, REsp. no. 154.733, 4a Turma, Rel. Min. } \\
\text { Francisco Cesar Asfor Rocha, j. em 05/12/2000; e } \\
\text { - STJ, REsp. no. 1.552.548/MS, 4a Turma, Rel. Min. } \\
\text { Marco Buzzi, j. em 06/12/2016 }\end{array}$ \\
\hline $\begin{array}{l}\text { Julgados que entenderam não ser } \\
\text { possível a interversio possessionis da } \\
\text { posse precária }\end{array}$ & $\begin{array}{l}\text { - STJ, REsp. no. 844.098/MG, 3a Turma, Rel. Min. } \\
\text { Nancy Andrighi, Rel. p/ Acórdão Min. Sidnei Beneti, j. } \\
\text { em 06/11/2008 }\end{array}$ \\
\hline $\begin{array}{l}\text { Julgados que não analisaram a } \\
\text { matéria, nem mesmo } \\
\text { tangencialmente, em decorrência da } \\
\text { Súmula no. } 07 .\end{array}$ & $\begin{array}{l}\text { - } \quad \text { STJ, AgInt. no AREsp. no 1.172.704/PR, 4a Turma, } \\
\text { Rel. Min. Luis Felipe Salomão, j. em 27/02/2018; } \\
\text { - STJ, AgInt. no AREsp. no 990.262/SP, 4a Turma, } \\
\text { Rel. Min. Conv. Lázaro Guimarães, j. em 06/02/2018; } \\
\text { - STJ, AgInt. no AREsp. no 1.012.678/GO, 4a Turma, } \\
\text { Rel. Min. Luis Felipe Salomão, j. em 26/09/2017; } \\
\text { - STJ, AgInt. no AREsp. no 800.813/SP, 4a Turma, } \\
\text { Rel. Min. Maria Isabel Gallotti, j. em 02/08/2016; } \\
\text { - STJ, AgRg. no AREsp. no 473.529/SC, 3a Turma, } \\
\text { Rel. Min. Paulo de Tarso Sanseverino, j. em } \\
\text { 06/08/2015; } \\
\text { - STJ, AgRg. no REsp. no 1.299.340/CE, 4a Turma, } \\
\text { Rel. Min. Luis Felipe Salomão, j. em 24/03/2015; } \\
\text { - STJ, AgRg no REsp. no 1.415.166/SC, 3a Turma, } \\
\text { Rel. Min. Marco Aurelio Bellizze, j. em 21/10/2014; } \\
\text { - STJ, AgRg. no AREsp. no 180.559/RS, 4a Turma, } \\
\text { Rel. Min. Luis Felipe Salomão, j. em 17/12/2013; } \\
\text { - STJ, REsp. no 932.972/RS, 4ạ Turma, Rel. Min. Luis }\end{array}$ \\
\hline
\end{tabular}




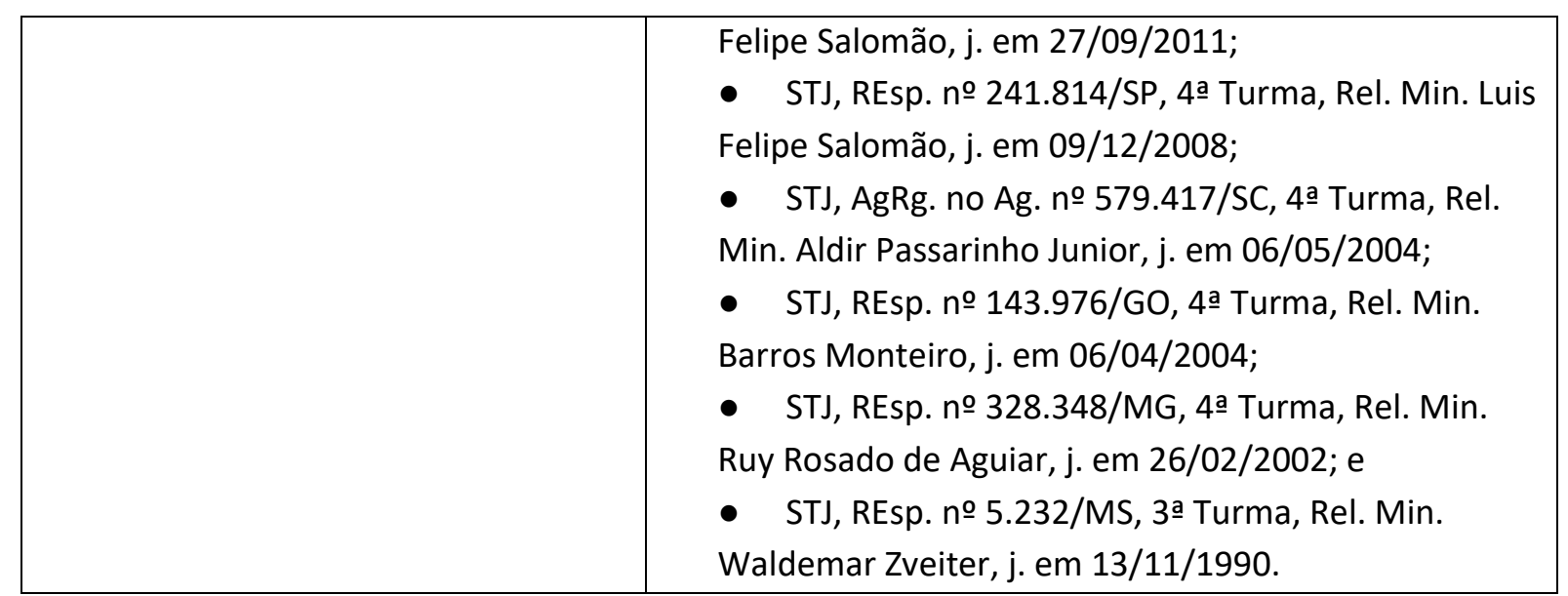

Fonte: Elaboração própria, 2020.

Graficamente, a pesquisa revela a seguinte estatística:

Gráfico 1 - Estatística de julgados do Superior Tribunal de Justiça (STJ) sobre interversão possessória da precariedade.

\section{Posse precária convalesce \\ Posse precária não convalesce \\ - Súmula no 07 \\ Julgados sobre outra matéria envolvendo posse precária}

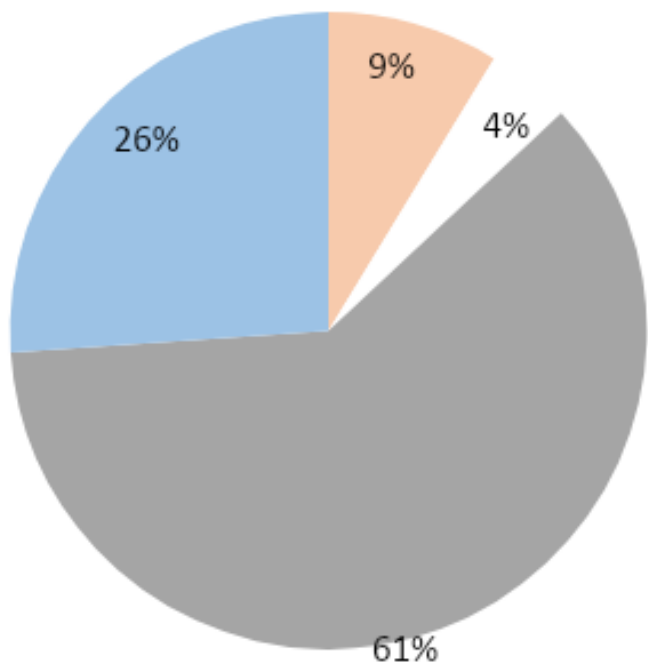

Fonte: Elaboração própria, 2020.

Observe que, a respeito da matéria, o Superior Tribunal de Justiça se divide, não apresentando jurisprudência em torno da possibilidade de interversão da posse precária. Contudo, há precedentes favoráveis e contrários.

O primeiro precedente é o Recurso Especial no. 154.733/DF, que reconheceu a usucapibilidade de coisa fundada em posse precária: 
CIVIL. USUCAPIÃO EXTRAORDINÁRIO. COMPROVAÇÃO DOS REQUISITOS. MUTAÇÃO DA NATUREZA JURÍDICA DA POSSE ORIGINÁRIA. POSSIBILIDADE. O usucapião extraordinário - art. 55, CC - reclama, tão-somente: a) posse mansa e pacífica, ininterrupta, exercida com animus domini; b) o decurso do prazo de vinte anos; c) presunção juris et de jure de boa-fé e justo título, "que não só dispensa a exibição desse documento como também proíbe que se demonstre sua inexistência". E, segundo o ensinamento da melhor doutrina, "nada impede que o caráter originário da posse se modifique", motivo pelo qual o fato de ter havido no início da posse da autora um vínculo locatício, não é embaraço ao reconhecimento de que, a partir de um determinado momento, essa mesma mudou de natureza e assumiu a feição de posse em nome próprio, sem subordinação ao antigo dono e, por isso mesmo, com força ad usucapionem. Precedentes. Ação de usucapião procedente. Recurso especial conhecido, com base na letra "c" do permissivo constitucional, e provido. (STJ, REsp. №. 154.733, 4a Turma, Rel. Min. Francisco Cesar Asfor Rocha, j. em 05/12/2000).

O Recurso Especial discutia matéria envolvendo a propositura de uma ação de usucapião em face de uma empresa em Taguatinga-DF. Segundo consta no voto do Relator, a usucapiente propôs a ação em 1992, quando contava 23 anos de posse contínua e pacífica. Socialmente era reconhecida como proprietária, pagava os tributos incidentes e realizou benfeitorias e acessão no imóvel. No início da relação locatária, a usucapiente pagava os alugueres à empresa, o que cessou posteriormente, nunca mais pagando aluguel e tampouco foi instada a pagar.

O juízo de piso julgou procedente a ação. Recorrendo a empresa proprietária ao Tribunal de Justiça do Distrito Federal e Territórios (TJDFT), a 2a Turma Cível reformou a decisão de piso, entendendo não estarem presentes requisitos de configuração da usucapião: "a decisão reformadora desprestigiou o requisito da posse, por ter sido ela originada de avença locatícia e, segundo a Turma Julgadora, insusceptível de ter a sua natureza transfigurada, com aptidão para gerar o usucapião" [sic]. Este é o trecho do Acórdão da Apelação do TJDFT que consta no Voto do Relator do Recurso Especial:

Civil. Usucapião. Ausência dos requisitos específicos. Sentença Reformada. Provimento da Apelação. 1. Para obter o domínio da coisa por via de usucapião, exigem-se, além dos requisitos genéricos intrínsecos da petição inicial, os requisitos específicos, não se admitindo possa o usucapiente, unilateralmente, mudar a natureza da posse. 2. Em decorrência, e porque evidenciado que a posse teve origem em relação locatícia, expressamente admitida pela autora, desmerece prestigiada a sentença que, olvidando esse pormenor, acolhe a pretensão deduzida. 3. Apelo Provido.

A usucapiente recorreu ao STJ. O Relator, Min. Francisco Cesar Asfor Rocha, entendeu ter havido a interversio possessionis a partir do momento em que a precarista passou a agir como se fosse proprietária, em detrimento da resignação da empresa: 
Admitindo-se que de início tenha havido, mesmo que no plano intencional, a relação locatícia, nada impediria a transmudação da natureza da posse, em decorrência de fatores circunstanciais, notadamente o abandono por parte do proprietário que em nenhum momento cuidou de implementar os cometimentos impostos ao locador, v.g.: a instrumentalização da avença; a cobrança dos aluguéis; o manejo das ações cabíveis para reprimir a mora etc. etc. A esse desiderato, tenho como presente e acoplo o entendimento de [nome omiti], segundo o qual - "o que possuía como Locatário, por exemplo, desde que tenha repelido o proprietário, deixando de pagar os aluguéis e fazendo-lhe sentir, inequivocadamente a sua pretensão dominial, é fora de dúvida que passou a possuir como dono" (Da Prescrição Aquisitiva, $3^{\mathrm{a}}$ ed., $\mathrm{n}^{\circ}$ 22, pág. 123). Em conseqüência, válida, também, a argumentação segundo a qual: "O animus domini está presente, tanto mais porque, no usucapião o critério para a sua aferição é objetivo, resultando de atos que revelam, ostensiva e cumpridamente, a sinceridade da crença do usucapiente em ser dono das terras". (Revista dos Tribunais, vol. 567, pág. 214). Tomado tudo isso em consideração e tendo-se em conta a situação contextual dos autos, tenho que a decisão divergente melhor aplicou o direito à espécie, porque lastreada em diretriz que melhor revela os requisitos do usucapião extraordinário, assim sintetizada: 'É certo, outrossim, segundo o ensinamento da melhor doutrina, que 'nada impede que o caráter originário da posse se modifique', motivo pelo qual o fato de ter havido no início da posse da autora um vínculo locatício, não é embaraçado ao reconhecimento de que, a partir de um determinado momento, essa mesma mudou de natureza e assumiu a feição de posse em nome próprio, sem subordinação ao antigo dono e, por isso mesmo, com força ad usucapionem'. 'Assim, a relação locatícia de que cogita a v. sentença é um acontecimento antigo, perdido na noite do tempo, e que foi definitivamente substituído pelo fato atual e inconteste da posse animo domini da autora, que já vem perdurando há muito mais de vinte anos'. Na esteira dessas considerações, dou provimento ao recurso e restabeleço a sentença de primeiro grau. É como voto.

Já em 2007 e 2008, no Recurso Especial no. 844.098/MG, que tramitou na 3a Turma, os Ministros componentes deste órgão divergiram substancialmente quanto à caracterização jurídica da existência de posse ad usucapionem em um caso envolvendo alienação fiduciária.

A Relatora do processo foi a Min. Nancy Andrighi, mas outros Ministros pediram vistas sucessivas do recurso, divergindo da Relatora.

Tratava-se de caso de ação de usucapião extraordinária de bem móvel (um carro), proposta pela ora recorrente, em face de um Banco que financiou a aquisição do veículo por outra pessoa (devedora fiduciária).

Em 1997, a recorrente comprou da devedora da alienação fiduciária junto ao Banco o veículo financiado, pagando o respectivo preço e exercendo a posse mansa, pacífica e ininterrupta do veículo por 07 anos, sem oposição do Banco recorrido. Requereu a aquisição da sua propriedade mediante usucapião, nos termos do art. 1.261 do Código Civil. 
A sentença julgou improcedente o pedido, "sob o fundamento de que o veículo em questão estava gravado com cláusula de alienação fiduciária em garantia decorrente de contrato firmado entre o ora recorrido e a pessoa que negociou o veículo com a ora recorrente".

O Acórdão do Tribunal de Justiça do Estado de Minas Gerais negou provimento à apelação da ora recorrente no Recurso Especial:

USUCAPIÃO - CERCEAMENTO DE DEFESA - INOCORRÊNCIA - VEÍCULO ALIENAÇÃO FIDUCIÁRIA - PRESCRIÇÃO AQUISITIVA - IMPOSSIBILIDADE ANIMUS DOMINI - AUSÊNCIA - Se os documentos contidos nos autos permitem com segurança o julgamento do processo nos termos do artigo 330, inciso I do Código de Processo Civil sem a necessidade da instrução probatória, não há que se falar em cerceamento de defesa. - A cessão a terceiro de veículo objeto de alienação fiduciária em garantia, na vigência do contrato, não é suscetível de aquisição pelo cessionário, via usucapião, em face da ausência do requisito indispensável do animus domini. Inteligência do artigo 619 do Código Civil.

O Recurso Especial proposto alegava violação ao art. 1.261 do Código Civil de 2002, equivalente ao art. 619 do CC/1916, porque, "ao contrário do entendimento do acórdão recorrido, estariam presentes os requisitos exigidos para a configuração da usucapião prevista no referido artigo".

Em seu voto, a Relatora entendeu que a recorrente exercia "posse própria" sobre o bem, que é a "posse como dono, a posse da coisa como sua". Nesse sentido, prosseguiu dizendo que "encontra-se equivocado o acórdão recorrido ao afirmar que para a aquisição da propriedade pela usucapião extraordinária é necessário o animus domini". E destacou, ainda:

Com efeito, de se notar o total descaso do recorrido para com o veículo em questão, porquanto se a devedora fiduciária tivesse deixado de cumprir o contrato de alienação fiduciária, nada justifica a inércia do ora recorrido em não ajuizar a ação competente para reaver a posse do veículo, o que poderia ter feito logo após a ocorrência do inadimplemento - mas que não foi feito até o momento.

Assim, para a Relatora, "a recorrente exerce uma posse autônoma, própria, que não depende, para existir, de qualquer relação jurídica negocial com o recorrido". Outrossim, "se o financiamento não foi pago, deve o recorrido cobrá-lo da devedora fiduciária". A partir disso, a Relatora votou por conhecer o Recurso Especial e deu-lhe provimento, reformando o acórdão recorrido, reconhecendo em favor da recorrente a usucapião extraordinária do veículo e declarar-Ihe a propriedade sobre o veículo. 
O Ministro Humberto Gomes de Barros pediu vista dos autos. Em seu voto-vista, o Ministro entendeu que no negócio que realizou com a devedora fiduciária, a recorrente não comprou o veículo, pois a devedora fiduciária detinha o bem como fiduciante, mantendo apenas a posse direta; a posse indireta e a propriedade (resolúvel) pertenciam ao Banco, credor fiduciário. Desse modo, para o Ministro, a recorrente, não adquiriu o veículo, porque quem o vendeu não tinha o domínio (típico caso de venda a non domino).

Segundo o Ministro, para averiguar a possibilidade de usucapião, é preciso, antes, determinar a existência de posse com base nos arts. 1.200 e 1.208 do Código Civil: "A posse injusta, porque violenta ou clandestina, pode dar ensejo à usucapião. Antes, porém, há que cessar a violência ou a clandestinidade".

Nessa interpretação sistemática, concluiu o Ministro que "não há, entretanto, no Código, previsão para que a posse precária autorize a aquisição do bem (por prescrição aquisitiva). Numa palavra: a posse precária não cessa, nem se converte". Esse entendimento já se opõe ao do Recurso Especial no. 154.733/DF, de 2000.

Prosseguindo, o Ministro Humberto Gomes de Barros entendeu que a posse da recorrente era clandestina:

A clandestinidade da posse da autora é evidente. Clandestina é a posse omitida de quem tinha verdadeiro interesse em conhecê-la. No caso, o banco (exatamente porque a usucapião somente a ele pode prejudicar). Não há prova de que o banco recorrido tenha sido informado da posse, o que faria cessar a clandestinidade. Só com a citação, portanto, houve ciência do banco, que permitiria o início do prazo da prescrição aquisitiva. Como o banco recorrido se opôs à pretensão da autora, ora recorrente, não se consumou a usucapião (prazo iniciado com a citação).

Porém, o Ministro entendeu que, além de clandestina, a posse da recorrente também era precária:

Se o fiduciante se torna inadimplente perante o banco fiduciário, a posse que era justa e direta torna-se precária. Porque precária é a posse de quem tem o dever de restituí-la quando reclamada por quem de direito. O fiduciante inadimplente tem o dever de restituir a posse direta ao proprietário fiduciário. Se não o faz, expõe-se à busca e apreensão. Não importa que o fiduciante transmita a terceiro a posse direta da coisa antes de tornar-se inadimplente. Com o inadimplemento, a posse é contaminada e torna-se precária, seja quem for o possuidor.

Entendeu o Ministro, então, que se a devedora fiduciária estiver inadimplente, a posse da recorrente é precária e, consequentemente, não induz usucapião, pois o Banco fiduciário tem o direito de exigir a devolução da coisa de quem a detenha. Isso posto, votou pelo não provimento do 
Recurso Especial, sendo acompanhado pelo Ministro Ari Pargendler. O Ministro Sidnei Beneti pediu vista.

Esse último Ministro entendeu que a situação versa, tão somente, sobre posse clandestina, e que, por questões contratuais, a situação fática não foi capaz de gerar usucapião:

Com efeito, a posse de bem por contrato de alienação fiduciária em garantia não pode levar a usucapião, por mais que passe o tempo, seja pelo adquirente, seja por cessionário deste, porque essa posse remonta ao fiduciante, que é a financiadora, a qual, no ato do financiamento, adquire a propriedade do bem, cuja posse direta passa ao comprador fiduciário, conservando a posse indireta (Ihering) e restando essa posse como resolúvel por todo o tempo, até que o financiamento seja pago. A posse é justa enquanto válido o contrato. Ocorrido o inadimplemento, transforma-se em posse injusta, incapaz de gerar direito a usucapião, não preenchendo os requisitos do art. 1261 do Cód. Civil/2002, equivalente ao art. 619 do Cód. Civil/1916. Atente-se, ainda, ao que dispõe o art. 1208 do Cód. Civil/2002 (correspondente ao art. 497 do Cód. Civil/1916): “Não induzem posse os atos de mera permissão ou tolerância, assim como não autorizam a sua aquisição os atos violentos, ou clandestinos, senão depois de cessar a violência ou a clandestinidade". A clandestinidade, no caso de conservação do bem ao inadimplemento do contrato de alienação fiduciária e cessão a terceiro é evidente, de maneira que, a rigor, no caso, nem mesmo se tem posse, nem mesmo direta, mas mera detenção, que não pode transformarse em posse "ad usucapionem" por mais que passe o tempo - visto que "quod ab initio vitiosum est, non potest tractu temporis convalescere".

Nesse sentido, o Ministro entendeu ser impossível a transmudação em da natureza da posse ad usucapionem do bem recebido em alienação fiduciária em garantia, razão pela qual não "conheceu" do Recurso Especial. (Na linguagem própria da 3a Turma, isso significa "negar provimento").

Apesar de fundamentar seu voto-vista na existência de uma posse clandestina não convalescida, parece que os argumentos do Ministro estão mais direcionados a uma descrição da posse precária.

Finalmente, a ementa do Acórdão do Recurso Especial no. 844.098/MG ficou assim:

CIVIL. USUCAPIÃO. VEÍCULO. ALIENAÇÃO FIDUCIÁRIA. INADIMPLEMENTO. PRESCRIÇÃO AQUISITIVA. IMPOSSIBILIDADE. POSSE INJUSTA. I.- A posse de bem por contrato de alienação fiduciária em garantia não pode levar a usucapião, seja pelo adquirente, seja por cessionário deste, porque essa posse remonta ao fiduciante, que é a financiadora, a qual, no ato do financiamento, adquire a propriedade do bem, cuja posse direta passa ao comprador fiduciário, conservando a posse indireta (IHERING) e restando essa posse como resolúvel por todo o tempo, até que o financiamento seja pago. II.- A posse, nesse caso, é justa enquanto válido o contrato. Ocorrido o inadimplemento, transforma-se em posse injusta, incapaz de gerar direito a usucapião. Recurso Especial não 
conhecido. (STJ, REsp. no. 844.098/MG, 3a Turma, Rel. Min. Nancy Andrighi, Rel. p/ Acórdão Min. Sidnei Beneti, j. em 06/11/2008).

Em 2016, o Tribunal foi instado a se manifestar novamente sobre hipótese de transmudação, no REsp. no 1.552.548/MS, que tramitou na 4aㅡ Turma:

\begin{abstract}
RECURSO ESPECIAL - USUCAPIÃO EXTRAORDINÁRIA - INSTÂNCIAS ORIGINÁRIAS QUE JULGARAM IMPROCEDENTE OS PEDIDOS - POSSE AD USUCAPIONEM E POSSE PRECÁRIA - TRANSMUDAÇÃO DA SUA NATUREZA POSSIBILIDADE - NÃO OCORRÊNCIA NA ESPÉCIE - INEXISTÊNCIA DE ALTERAÇÃO FÁTICA SUBSTANCIAL ENTRE A AQUISIÇÃO DA POSSE E O SEU EXERCÍCIO - CONTRATO DE COMODATO - RECURSO ESPECIAL DESPROVIDO. Hipótese: A presente controvérsia consiste em aferir se, para fins de usucapião extraordinário, a posse originariamente precária pode transmudar-se a dar ensejo àquela exercida com animus domini. 1. Tanto sobre a égide do Código anterior, quanto do atual, os únicos requisitos exigidos para a aquisição da propriedade por usucapião extraordinário [sic] são a posse ad usucapionem e o prazo previsto em lei. 2. Para fins de aquisição da propriedade por usucapião admite-se tanto a acessão na posse, accessio possessionis, quanto a sucessão na posse, ou successio possessionis. 3. No caso dos autos, verifica-se que mesmo com a morte da primeira posseira, não houve alteração fática substancial a ponto de conduzir à transmudação da posse por ela exercida, já que durante todo o tempo a relação jurídica estabelecida entre as partes foi regida pelo comodato, primeiro verbal, depois escrito. Nas hipóteses em que a alteração fática autorizar, admite-se a transmudação da natureza da posse para fins de configuração de usucapião, todavia, tal não ocorreu na espécie, em que a posse originariamente adquirida em caráter precário, assim permaneceu durante todo o seu exercício. 4. Recurso especial não provido. (STJ, REsp. no. 1.552.548/MS, 4aㅡ Turma, Rel. Min. Marco Buzzi, j. em 06/12/2016).
\end{abstract}

Conforme se verifica da análise do início e do final da ementa do Acórdão, o órgão entendeu que a posse precária pode ser convertida em ad usucapionem: "POSSE AD USUCAPIONEM E POSSE PRECÁRIA - TRANSMUDAÇÃO DA SUA NATUREZA - POSSIBILIDADE - NÃO OCORRÊNCIA NA ESPÉCIE". Contudo, na situação fática, ou seja, naquele caso específico, não houve tal conversão, pois a tença manteve o título de precária a todo momento. Conclusão: esse julgado admite a interversio possessionis da posse precária.

Nesse sentido, a conversão da tença a título de precariedade em posse ad usucapionem não apresenta entendimento uniforme e convergente no âmbito da instância especial. E isso não só pela confusão entre precariedade e clandestinidade, mas, também, por ora se reconhecer que a tença precária não gera usucapião, ora sim.

\title{
5. A USUCAPIÃO URBANA INDIVIDUAL E COLETIVA DECORRENTE DA CONVALIDAÇÃO DA TENÇA PRECÁRIA: GARANTIA DE MORADIA E TRABALHO.
}


A posse tem, segundo Cornelia Munteanu (2008), uma certa "beatitudine" ("beatitude"), pois é o coração dos direitos sobre as coisas ("inima dreptului proprietății" ou "cœeur du droit des biens"). Por isso, aquele que exerce os poderes úteis sobre a coisa exerce uma posse verdadeira e que merece ser protegida.

Então, não há motivos que justifiquem considerar o poder que o precarista exerce sobre a coisa como uma mera detenção ao invés de uma posse que cumpre sua função socioeconômica, principalmente quando se fala em exercício de uma posse com aspectos sociais.

Existe, presentemente, uma classificação da posse em paralelo àquelas tradicionais e conhecidas de há muito. Luciano de Camargo Penteado (2014, p. 623) fala em uma classificação pelo aspecto social ou pela qualificação da posse. Daí que existiria a:

- $\quad$ Posse trabalho: aquela que se exerce com desempenho de atividade laborativa e produtiva sobre o bem;

- $\quad$ Posse social: aquele exercida para fins de moradia ou laborativos por pessoas pobres, que receberão uma especial tutela por esse motivo;

- $\quad$ Posse moradia: aquela destinada à habitação do possuidor e de sua família;

- Posse legitimada: aquela que resulta do reconhecimento pelo poder público municipal, via título de legitimação, e destinada à regularização fundiária e posterior aquisição da propriedade.

Essa classificação da posse repercute em modalidades de usucapiões que terão prazos e requisitos mais favoráveis ao usucapiente.

A "precariedade" da posse (rectius: detenção ou possessio naturalis) que decorria dos contratos de precarium, precario, precaria e stipendium - e que seria uma condição imodificável ad perpetuam, mesmo após anos de inadimplemento - é, ao que tudo indica, a raiz de tratar a posse precária como insanável. O inadimplemento nos contratos reais, hoje, se aproxima daquela ideia romana de inadimplemento do precario. Daí a inevitável associação histórica. Porém, Roma era uma época diferente e de valores diferentes daqueles de hoje em dia. Um exemplo é o direito de propriedade, que não tem mais o caráter absoluto de antes e se sujeita, atualmente, a uma função social.

Há aqui, contudo, um "porém".

Marcus Eduardo de Carvalho Dantas (2016, p. 20-23), ao analisar a convalescença da precariedade para dar origem a uma posse justa, se opõe a falar em "saneamento pelo cumprimento da função social". Isso teria levado a uma situação em que, segundo ele, "nos tribunais fala-se em 
cumprimento da função social quando a posse de um terreno é utilizada para criação de galinhas". Adverte que há modalidades de usucapião que não exigem que o usucapiente se comporte dentro dos padrões característicos da função social, ou seja, não exerce a posse para moradia e como fonte de trabalho.

Adaptando esse entendimento para o saneamento do vício da precariedade, se se está a condicionar a interversio possessionis da tença precária ao cumprimento de uma função social da posse, então não há que se falar da possibilidade de ocorrer a usucapião extraordinária do caput do art. 1.238 do Código Civil nessa hipótese. Nessa modalidade pode haver a usucapião mesmo com o imóvel lacrado e desusado por anos (desde que não configure derrelição). Que função social há nessa posse?

Logo, só há coerência em associar a interversio possessionis da tença precária ao cumprimento de uma função social se a "posse precária" for pro morada, pro labore e/ou pro misero, ou seja, naquelas hipóteses de usucapiões especiais, como a rural e a urbana (individual e coletiva).

Desse modo, a ideia de que o simples apossamento pelo precarista já significa a virtude de cumprir a função social da posse não é adequada; pode ser, inclusive, que o esbulhado tenha melhores intenções socioeconômicas a dar àquela coisa.

Dar função social significa utilizar uma coisa de modo socialmente relevante, como moradia e trabalho. Assim, criar galinhas (DANTAS, 2016, p. 20-23) pode significar o cumprimento da função social, desde que seja, por exemplo, o sustento de uma família carente.

Por exemplo, Emerson Affonso da Costa e Moura e Maurício Jorge Pereira da Mota (2015, p. 1301) esclarecem que as questões problemáticas em torno da habitação urbana não são consequência tão-somente do parcelamento do solo urbano de maneira irregular, ou os núcleos urbanos sem infraestrutura e condições de habitação, ou a ocupação de áreas de proteção ambiental.

Faz todo sentido, pois em paralelo a tudo isso há também a regularização da posse e da propriedade de muitas famílias - geralmente pobres - , que têm na usucapião especial urbana (seja individual, seja coletiva) seu instrumento de efetivação do seu direito de domínio e de moradia.

Josué Mastrodi e Ederson dos Santos Alves (2017) afirmam que após a Recomendação Geral no 4 do Comitê das Nações Unidas para Direitos Sociais, Econômicos e Culturais, o direito de moradia deve ser garantido de maneira adequada, e uma das formas de se garantir tal adequação é por meio da segurança jurídica da posse. Segundo escrevem, esse elemento consiste no seguinte: 
temporal contra desalojamento forçado, independentemente do tipo de posse, evitando qualquer ameaça ou lesão ao direito de moradia, uma vez que essa falta de proteção compromete ou deteriora a qualidade de vida dessas pessoas. Assim, caberia aos Estados-Parte do PIDESC trabalharem visando à construção dessa segurança (MASTRODI e ALVES, 2017, p. 35).

Logo, o imóvel urbano utilizado pro morada, ainda que se trate de tença precária, deve ter sua posse garantida, protegida e assegurada, como um compromisso assinado pelos Estados junto às Organizações das Nações Unidas. Veja, então, que há um argumento a mais a favor da interversio possessionis, pelo menos para fins de proteção da posse pro morada, pro labore e pro misero em perímetro urbano.

Além disso, Josué Mastrodi e Ana Carolina Batista (2016, p. 1552) questionam se existe um "direito fundamental à posse" e identificam que "mais do que a simples relativização do conceito de propriedade, é possível defender, no âmbito da propriedade urbana, a subordinação da propriedade do imóvel residencial urbano à moradia - direito social fundamental que, concretamente, identifica o uso efetivo do imóvel segundo sua função social".

Defendem que a posse é muito mais que um componente do direito de propriedade: é a base do direito de moradia, que é a "aplicação finalística e concreta do uso de uma propriedade urbana". Logo, sendo a moradia um direito fundamental, a posse para fins de moradia é um direito fundamental (MASTRODI e BATISTA, 2016, p. 1552).

Imagine, agora, alguém ou um núcleo urbano que detenha precariamente um imóvel — não por se tratar de bem público, mas por se tratar de negócio jurídico entre particulares cuja restituição da coisa foi inadimplida - e que tem sido utilizado para fins de moradia ou trabalho por anos. Essa circunstância não é a de uma mera tença; há um interesse da sociedade em considerar relevante essa situação, especialmente se se tratar de pessoas pobres. Nesse contexto, faz todo sentido em se falar de um direito à posse daqueles que permaneceram usufruindo e dando finalidade lícita ao bem. Ou seja, em outras palavras: esses detentores, nessas condições, têm um direito à interversio possessionis da tença precária em posse ad usucapionem para, no espaço urbano, regularizar sua situação dominial.

E, mais uma vez, se verifica que que a precariedade do art. 1.200 do Código Civil não pode ser lida, interpretada e aplicada a partir da precariedade romana. A precariedade de hoje não tem os contornos da precariedade daquele momento histórico. Na Roma clássica, imperial e pós-clássica (antiguidade tardia) a precariedade foi concebida justamente para isto: ser detenção perante o possuidor originário (para afastar a possibilidade de usucapião) e ser posse ad interdicta perante penitus extranei ao negócio de precarium e precario. 
Então, faz realmente sentido manter essa leitura histórica do vício? Parece que não, pois esta leitura se perdeu com o tempo e a ideia de precariedade é outra, afinal, o precarista um dia foi possuidor direto da coisa, e não necessariamente um detentor.

Então, hoje, por que a precariedade seria insanável se sequer existe uma proibição expressa nesse sentido? Por causa da gravidade não há de ser, afinal, abusar da confiança não é mais grave que um ato de violência, a priori.

Pois bem. A conclusão a que se chega é a de que a precariedade de hoje (vício) é bem diferente daquela inicialmente concebida em Roma; logo, não faz sentido lê-la hoje a partir dos efeitos do precarium, do precario, da precaria e do stipendium, pois não há a necessária correspondência. De modo que a função social da posse - cumprida nas condições de pro morada, pro labore e pro misero - mitiga a impossibilidade de convalescença da tença precária, como forma de ensejar a usucapião especial urbana individual ou coletiva para a garantia da moradia e do trabalho.

\section{CONCLUSÃO}

A interversio possessionis - mediante posse pro morada, pro labore e pro misero - garante ao detentor precário que, pela usucapião (especialmente a urbana), tenha segurança jurídica da posse e tenha garantidos seus direitos de moradia e de trabalho. Porém, apesar disso, não há consenso nem na literatura jurídica e nem na instância especial sobre a interversio possessionis da tença precária em posse ad usucapionem.

Primeiro porque "precariedade" se revelou um conceito - em sentido histórico e jurídico polissêmico, assumindo significados como: ato de liberalidade; contrato de empréstimo livremente revogável (revogabilidade ad nutum), modalidade absorvida pelo comodato com o passar do tempo; detenção; posse ad interdicta; vício subjetivo; vício formal; ausência de título; título nulo (ou legitimidade do título); e posse de má-fé.

E segundo porque a associação (inevitável) da precariedade com o abuso de confiança parece dar conotações mais gravosas a esse vício, de modo a se verificar uma resistência em considerar que situação como essa possa beneficiar o precarista com a aquisição da propriedade via usucapião.

Mas entendimentos recentes e já utilizados no Superior Tribunal de Justiça têm pugnado pela possibilidade de interversio possessionis em caso de detenção precária. 
Essa pesquisa identificou que a inversão do título pela presença do animus domini, que antes da precariedade era ausente (ou irrelevante), torna-se requisito essencial para a interversão. $\mathrm{Na}$ verdade, trata-se do animus rei sibi habent: não necessariamente será a intenção de ser dono, mas de agir como dono, expressando a imago domini (teoria objetiva). Assim, a interversão teria lugar a partir do modo como precarista passou a se comportar em relação à coisa e ao possuidor.

Após refletir sobre a convalescença ou não da detenção precária em posse ad usucapionem, constatou-se que não há um porquê, um motivo ou uma razão para não reconhecer sua possibilidade. Ao contrário: se se utilizar a regulæ juris da função social da posse para a interpretação das regras jurídicas, então a interversão do título será obrigatória, pois será garantida a propriedade a quem dá utilidade e atende aos interesses socioeconômicos da coisa.

Mas, a associação da interversio possessionis da tença precária ao cumprimento de uma função social foi feita somente em relação à "posse precária" pro morada, pro labore e/ou pro misero, ou seja, naquelas hipóteses de usucapiões especiais.

Se o não reconhecimento da interversio possessionis da detenção nesses casos de precariedade for devido à proteção da confiança contratual individual - decorrente de deveres de eticidade que incidem sobre relações particulares -, então a função social da posse acabará por se sobrepor à proteção da confiança, uma vez que as consequências da interpretação das regras conforme à função social atendem aos interesses sociais quanto à correta destinação socioeconômica das coisas.

Aliás - sendo um pouco historicista-pandectista - , sequer razões históricas existem para não admitir essa inversão do título. É que precario não é, historicamente, um vício, mas um contrato.

Ao que tudo parece indicar, a precariedade como vício é uma associação feita com o inadimplemento na devolução da coisa no precarium e no precario da tradição romanística e na precaria da tradição canônica. O precario accipiens (precarista) não poderia usucapir o bem porque não tinha posse perante o precario dans (concedente); era detentor. Só que ele era detentor durante o contrato e também após o inadimplemento.

Assim, a figura do precarium foi concebida para que o precario accipiens nunca tivesse posse e nunca usucapisse perante o precario dans. Mas isso não tem a ver com uma viciosidade do precarium, mas sim com o seu regime legal-contratual.

De modo que associar - conceitualmente ou quanto aos efeitos - o vício da precariedade do art. 1.200 do Código Civil à "detenção precária" do Direito Romano para não conceber a interversão possessória e a usucapibilidade, não é uma interpretação histórica correta. 
Parece, então, não existir mais qualquer ratio legis ou ratio juris para a inconversibilidade da tença precária em posse. Se existiu algum dia, a função social da posse, a segurança jurídica da posse nos espaços urbanos e o direito à moradia imunizaram do sistema jurídico; e se ainda existe, a regulæ juris da função social se sobrepõe a tais razões de ser.

\section{REFERÊNCIAS BIBLIOGRÁFICAS}

ALBERTARIO, Emilio. La possession romaine. In: Tijdschrift voor Rechtsgeschiedenis / Revue d'Histoire du Droit / The Legal History Review, vol. 12, ed. 11, p. 1-28, 1933.

AVENDAÑO VALDEZ, Jorge. Posesión ilegítima o precaria. In: Themis - Revista de Derecho, n. 4, Lima, p. 59 a 63, 1986.

AVENDAÑO VALDEZ, Jorge; MEJORADA CHAUCA, Martín; MORALES HERVIAS, Rómulo. Discusión en torno al Cuarto Pleno Casatorio Civil sobre el concepto de posesión precaria. In: lus Et Veritas, vol. 23, n. 47, p. 352-358, 2013.

BEVILÁQUA, Clóvis. Direito das Coisas. Brasília: Senado Federal, Conselho Editorial, 2003.

CARVALHO SANTOS, João Manoel de. Código Civil Brasileiro Interpretado. Vol. VIII. 11a ed. Rio de Janeiro: Forense, 1997.

CICERO, Cristiano. Interversio possessionis e irrilevanza dell'animus. In: Rivista Giuridica Sarda, vol. 20, ed. 3, p. 628-633, 2005.

COLIN, Ambroise Victor Charles; CAPITANT Henri. Cours élémentaire de droit civil français. Vol. II. Paris: Dalloz, 1914.

CORMACK, Geoffrey Mac. Naturalis possessio. In: Zeitschrift der Savigny - Stiftung für Rechtsgeschichte: Romanistische Abteilung, vol. 84, ed. 1, 1880.

COSTA, Dilvanir José da. O sistema da posse no direito civil. In: Revista de Informação Legislativa, vol. 35, n. 139, p. 109-117, jul./set. 1998.

DANTAS, Marcus Eduardo de Carvalho. Toda posse ad usucapionem é uma posse injusta. In: Civilistica.com. Rio de Janeiro, a. 5, n. 1, 2016, pp. 01-33.

DANTAS, Marcus. Análise crítica sobre a extensão do elenco de vícios da posse e suas consequências. In: Revista de Informação Legislativa, ano 50, n. 197, p. 29-50, jan./mar. 2013.

DE GIORGI, Maurizio. L'usucapione. Aspetti sostanziali e profili processuali controversi. Milano: Giuffrè, 2011. 
DE LAS CASAS, Gerson Baboza. Las vicisitudes de la posesión precaria. Un análisis histórico de la institución y su consolidación como posesión contraria a derecho y justificación para la tutela de la propiedad. In: Boletín sobre temas de Derecho, 07 de noviembre de 2019.

DINIZ, Maria Helena. Curso de Direito Civil Brasileiro. Vol. 4: Direito das Coisas. 20ā ed. São Paulo: Saraiva, 2004.

ESPÍNOLA, Eduardo. Posse, propriedade, compropriedade, direitos autorais. Rio de Janeiro: Conquista, 1956.

FERRETTI, Paolo. II possesso tra animus e corpus: da Labeone a Paolo. In: FERRETTI, Paolo; FIORENTINI, Mario (a cura di). Formazione e trasmissione del sapere: diritto, letteratura e società. VI incontro tra storici e giuristi dell'antichità. Trieste: EUT Edizioni Università di Trieste, 2020, pp. 1136.

GONÇALVES, Marcus Vinícius Rios. Dos vícios da posse. 4a ed. Porto Alegre: Juarez de Oliveira, 2008. IHERING, Rudolf von. Fundamento dos interditos possessórios. Tradução de Adherbal de Carvalho. Bauru: EDIPRO, 2007.

JOSSERAND, Louis. Cours de droit civil positif français. Vol. III, T. I. 3ạ ed. Paris: Sirey, 1938.

JUSTO, António dos Santos. Precário: direito romano (breve referência aos direitos contemporâneos). In: Lusíada Direito, n. 13, Lisboa, p. 36-101, 2015.

LAMA MORE, Héctor Enrique. La posesión y la posesión precaria en el derecho civil peruano. El nuevo concepto del precario y la utilidad de su actual regulación en el derecho civil peruano. Tesis de Magister. Pontificia Universidad Católica del Perú. Lima, 2011.

LEMAITRE, Fernando Atria. El sistema de acciones reales, parte especial: la acción de precario. In: Revista de Derecho, vol. XXX, n. 2, p. 57-86, dic. 2017.

LINS, Edmundo Pereira. Ensaio sobre a posse - Capítulo III. In: Revista da Faculdade de Direito da UFMG, vol. 9, p. 155-174, jan. 1914.

LOUREIRO, Francisco Eduardo. Direito das Coisas. In: PELUSO, Cezar (Coord.). Código Civil Comentado. Doutrina e Jurisprudência. 5a ed. São Paulo: Manole, 2011.

MACCORMACK, Geoffrey. lusta and Iniusta Possessio. In: Tijdschrift voor Rechtsgeschiedenis / Revue d'Histoire du Droit / The Legal History Review, vol. 42, issue 1, p. 71-80, 1974.

MADAIME, Marcio Manoel. A possibilidade de mudança do caráter da posse precária e sua utilidade para fins de usucapião. In: Revista de Direito Privado, n. 11, São Paulo, p. 188-213, 2002.

MASCIA, Katia. L'usucapione. La casistica giurisprudenziale di acquisto della proprietà di beni mobili e immobili e di altri diritti reali attraverso il decorso del tempo. Matelica: Halley, 2007.

MASTRODI, Josué; BATISTA, Ana Carolina. Existe um direito fundamental à posse? Estudo sobre a relativização do conceito de propriedade imobiliária urbana em face do direito de moradia. In: Revista de Direito da Cidade, vol. 7, n. 4, p. 1527-1554, fev. 2016. 
MASTRODI, Josué; ALVES, Ederson dos Santos. A segurança jurídica da posse como pressuposto do direito fundamental à moradia. In: Revista de Direito da Cidade, vol. 9, n. 1, p. 27-49, jan. 2017.

MELO, Marco Aurélio Bezerra de. Novo Código Civil Anotado. Vol. 5 - Direito das Coisas. Rio de Janeiro: Lumen Juris, 2003.

MENEZES CORDEIRO, António. A posse: perspectivas dogmáticas actuais. 3a ed. Coimbra: Almedina, 2004.

MOREIRA ALVES, José Carlos Moreira. Posse. Vol. I. Rio de Janeiro: Forense, 1997.

A detenção no direito civil brasileiro (conceitos e casos). In: CAHALI, Yussef Said (Coord.). Posse e propriedade: doutrina e jurisprudência. São Paulo: Saraiva, 1987.

MORENO MOCHOLÍ, Miguel. El precario. Barcelona: Bosch, 1951.

MOTA, Maurício Jorge Pereira da; MOURA, Emerson Affonso da Costa. O direito à moradia digna na regularização fundiária da lei federal no 11.977/2009: o caso do auto de demarcação da comunidade da Rocinha. In: Revista de Direito da Cidade, vol. 7, n. 3, p. 1292-1310, nov. 2015.

MUNTEANU, Cornelia. Câteva considerapii asupra posesiei în dreptul comparat (Quelques considérations sur la possession en droit comparé). In: Acta Universitatis Lucian Blaga. lurisprudentia, ed. 01/2008, p. 44-56, 2008.

OLIVECRONA, Karl. The acquisition of possession in Roman Law. Lund: C.W.K., 1938.

PENTEADO, Luciano de Camargo. Direito das Coisas. 3ạ ed. São Paulo: Revista dos Tribunais, 2014.

PIZARRO, Néstor A. La acción de despojo: Sus fuentes en el Derecho Canónico. In: Revista de la Universidad Nacional de Córdoba, año 30, n. 7/8, Córdoba, p. 843-893, setiembre-octubre 1943.

PLANIOL, Marcel; RIPERT, Georges. Traité pratique de droit civil français. Tome III. Les biens. 2a ed. Paris: LGDJ, 1955.

PONTES DE MIRANDA, Francisco Cavalcanti. Tratado de Direito Privado. Tomo X - Direito das Coisas: Posse. 3 a ed. Rio de Janeiro: Borsoi, 1971.

RESENDE, Astolfo de. A posse e a sua proteção. Vol. I. São Paulo: Sariava, 1937.

RIBEIRO, Benedito Silvério. Tratado de Usucapião. Vol. 1. 5ạ ed. São Paulo: Saraiva, 2007.

RICCOBONO, Salvatore. La teoria romana dei rapporti di possesso. La dottrine dei moderni e le legislazioni. In: Bullettino dell'Istituto di Diritto Romano, anno XXIII, fasc. I e II, Roma, p. 5-28, 1911.

Zur Terminologie der Besitzverhältnisse (Naturalis possessio, civilis possessio, possessio ad interdicta). Ristampa a cura di Pierangelo Buongiorno. In: Rivista di Diritto Romano, vol. XII, p. 132, 2012.

RODRIGUES, Sílvio. Direito Civil: Direito das Coisas. Vol. 5. 28a ed. Rio de Janeiro: Forense, 2003. 
S. F. D. [sic]. On the interversion of possession; or, whether a party may change the cause of his possession. In: The American Law Register, vol. 10, n. 2, New Series Vol. 1, pp. 65-81, dec. 1861.

SANTOS, José Augusto Lourenço dos. A transformação da posse precária em posse ad usucapionem pela inversão do título da posse. In: Revista do Instituto do Direito Brasileiro, ano 1, no 9. Faculdade de Direito da Universidade de Lisboa, Lisboa, 2012, pp. 5523-5531.

SAVIGNY, Frédéric Charles de. Traité de la possession en Droit Romain. Trad. de Ljenri Staedtler. 7. ed. Paris: Auguste Durand, 1866.

SCIALOJA, Vittorio. Sopra il «precarium» in Diritto Romano. 2 ed. Roma: Jovene, 1981.

SILVESTRE, Gilberto Fachetti. As alterações da Lei no. 13.465/2017 na usucapião especial urbana coletiva: questões materiais e processuais. In: Revista Direito da Cidade, vol. 11, n. 2, p. 337-367, 2019.

As teorias socioeconômicas da posse no Superior Tribunal de Justiça: aspectos materiais e aplicação processual. In: Revista Direito da Cidade, vol. 12, n. 2, p. 86-121, 2020.

TARTUCE, Flávio; SIMÃO, José Fernando. Direito civil. Vol.4 - direito das coisas. 2a ed. São Paulo: Método, 2009.

TORRES, Marcos Alcino de Azevedo; MOURA, Emerson Affonso da Costa. A vedação constitucional de usucapião dos bens públicos e a função social da propriedade: da mera detenção ao reconhecimento da posse funcionalizada pelos particulares. In: Revista de Direito da Cidade, vol. 10, n. 3, p. 19411965, ago. 2018.

VENOSA, Sílvio de Salvo. Direito civil. Vol. V. 10a ed. São Paulo: Atlas, 2010.

VOLTELINI, Hans. Prekarie und Benefizium. In: Vierteljahrschrift für Sozial - und Wirtschaftsgeschichte, 16, BD, H. 3/4, p. 259-306, 1922.

Trabalho enviado em 08 de julho de 2020

Aceito em 20 de julho de 2021 